\title{
WPS3629
}

\section{FISCAL SPACE FOR INVESTMENT IN INFRASTRUCTURE IN COLOMBIA}

\author{
Rodrigo Suescún* \\ The World Bank
}

\begin{abstract}
World Bank Policy Research Working Paper 3629, June 2005
The Policy Research Working Paper Series disseminates the findings of work in progress to encourage the exchange of ideas about development issues. An objective of the series is to get the findings out quickly, even if the presentations are less than fully polished. The papers carry the names of the authors and should be cited accordingly. The findings, interpretations, and conclusions expressed in this paper are entirely those of the authors. They do not necessarily represent the view of the World Bank, its Executive Directors, or the countries they represent. Policy Research Working Papers are available online at http://econ.worldbank.org.
\end{abstract}

\footnotetext{
• E-mail: rsuescun@worldbank.org. I thank Vivien Foster, Santiago Herrera, Rafael Herz, Guillermo Perry and Luis Servén for helpful comments and suggestions. Useful comments and discussions with Gabriel Piraquive and Alvaro Concha are also gratefully acknowledged, as is Mariana Fajardo's excellent research assistance.
} 


\begin{abstract}
For the evaluation of macroeconomic policies Colombian authorities rely heavily, if not exclusively, on the operational framework known as the Financial Programming Model developed by the IMF in the 1950s. Based on this static framework, the formulation of fiscal policy in the country, just as in various Latin American countries, focuses primarily on fiscal deficit and gross debt targets. However, the type of fiscal policy advice derived from it is not useful for understanding the asset-creating nature and the intertemporal trade-offs involved in public investment decisions. This paper develops a perfect foresight, dynamic small open economy model to provide an alternative framework for fiscal analysis and policy purposes. It is shown that the two competing frameworks deliver differing paths for the expected behavior of the Colombian economy. The proposed framework is then used to study the likely consequences of using public capital spending to achieve deficit targets since, in addition to an already high public debt, in the years ahead unfunded pension obligations will put enormous pressure on the Colombian government's solvency. The results indicate that public capital compression is costly in terms of foregone growth and very ineffective in achieving fiscal consolidation. The adoption of fiscal rules such as the golden rule or the permanent balance rule to shield public investment from undue budgetary pressures makes little sense in the presence of sustainability concerns. The paper shows that a transitory capital spending increase is not self-amortizing in the long run; hence an extra peso of public capital spending deteriorates the intertemporal fiscal position. A permanent increase largely pays for itself in terms of additional tax revenue but this effect is offset by a deterioration of infrastructure user charges, as long as public prices are determined competitively.
\end{abstract}

JEL: E62, H54, H55, H62 


\section{INTRODUCTION}

For the evaluation of macroeconomic policies Colombian authorities rely heavily, if not exclusively, on the operational framework known as the Financial Programming Model originally developed by Polack (1957) in the 1950s and further refined by the IMF (1987) and Mussa and Savastano (1999). Based on this analytical framework, and on a constitutional mandate that requires policy coordination, the Central Bank and the Ministry of Finance periodically agree on a Macroeconomic Program containing the policies needed to regulate aggregate demand and to ensure a sustainable growth path for the economy and the public accounts. National authorities summarize this policy design process as follows: “(...) As has been the case for many years, the program takes as given the inflation target, forecasts of monetary aggregates, the government's economic growth projection and the parameters of foreign exchange and fiscal policies. (...) Regarding fiscal policy, [the program] analyses revenue and expenditure goals and concludes with the analysis of the consistency of the public sector balance with the rest of economic variables" (Banco de la República, 1999). The IMF has a similar description: "In implementing the approach, the overall fiscal balance and public debt targets are set at levels which - in combination with other macroeconomic and structural polices - support specific output, inflation and balance of payments objectives, and ensure a sustainable (i.e., constant or declining) debt path" (IMF, 2004a).

There are fundamental weaknesses in this analytical approach. The analytical framework is essentially static, important variables such as the growth rate are determined exogenously and thus independently of the policies being assessed and the type of economic policies evaluated do not correspond to what modern macroeconomic theory understands for economic policy. The timing of policies is irrelevant, expectations play no role whatsoever and forward-looking behavior as well as the fact that agents make purposeful decisions is plainly ignored. ${ }^{1}$ Furthermore, the implicitly assumed connection between program designed policies and intertemporal fiscal solvency is unwarranted.

An issue for which the existing policy evaluation process is particularly ill equipped is the question of fiscal space for investment in infrastructure since decision-makers cannot evaluate the intertemporal trade-offs they face and thus cannot assess how current actions affect future behavior and performance or how future actions restrict the set of current feasible actions available. ${ }^{2}$ In the Financial Programming approach, policies are judged on the basis of their effect on conventional fiscal balance and gross public debt targets where the distinction between current and capital expenditures becomes blurred, intertemporal effects are overlooked and a bias against public investment may arise at times of fiscal retrenchment when it is clearer that investment is "the least rigid component of expenditure" (De Haan et al., 1996). In support of this last assertion, Echeverry et al. (2004) report recent data from the Colombian ministry of finance estimating in $97 \%$ the proportion of the central government budget that is "inflexible",

\footnotetext{
${ }^{1}$ For a more detailed critique of the Financial Programming Model see Edwards (1989).

${ }^{2}$ Other tools used by the IMF as analytical basis for policy advice and program design in middle income countries are the Balance Sheet Approach and the Debt Sustainability Analysis. These tools are not useful either to address the question at issue.
} 
meaning that the authorities cannot exercise discretion over most budgetary items in the short run. According to this account, the only flexible component is public investment.

The focus on fiscal deficit and debt targets may also bias public policies against capital spending by introducing arbitrary shortsighted debt limits which probably say nothing about the intertemporal solvency of the fiscal accounts. Debt limitations are explicitly introduced, for example, in the Colombian authorities' program with the IMF where an adjustor is included for September and December 2004 to allow for additional public investment provided the government receives higher-than-expected privatization proceeds (IMF, 2004b). But why should investment projects be funded from current revenues or today's taxpayers pay for the bill in its entirety if future generations of taxpayers will also benefit from the created infrastructure capital? In general, large investment projects will not be undertaken because their cost cannot be spread across generations by issuing debt. ${ }^{3}$

This criticism is not a minor theoretical point. Public investment compression may have sizeable adverse effects on growth and inequality. Calderón, Easterly and Servén (2003) argue that infrastructure investment cuts accounted for half or more of the reduction in Latin America's primary deficit over the last two decades with an estimated growth sacrifice of 1 percent per annum in the long-run growth rate of various economies. Calderón and Servén (2003) estimate that during this period Latin America's infrastructure gap relative to the seven successful economies of East Asia grew $40 \%$ to $50 \%$ for road length, $50 \%$ to $60 \%$ for telecommunications (main telephone lines) and by $90 \%-100 \%$ for power generation capacity. According to their estimates about one third of the increase in the average output gap between these two groups of countries is explained by the widening infrastructure gap. New empirical evidence has also shown that infrastructure development is an effective means of combating poverty through its direct positive effect on growth (Calderón and Servén, 2003; Loayza et al., 2003; and López, 2003) and through its effect on the income and welfare of the poor, on top of its impact on average income (Calderón and Servén, 2004; López, 2003).

This paper develops an alternative framework for policy analysis. The purpose of this paper is to construct a perfect-foresight dynamic general equilibrium model of endogenous growth of a small open economy to evaluate the effects of alternative fiscal policies. A calibrated version of the model is used to illustrate the effect of fiscal consolidation efforts in Colombia. Though the model in this paper is well suited for that particular endeavor, this paper is not about the design of a fiscal program. The focus of this paper is however circumscribed to assess the future space for public investment in infrastructure and the likely macroeconomic consequences of widening the existing public infrastructure gap. In addition to an already high public debt, in the years ahead future unfunded pension obligations will put enormous pressure on the Colombian government's solvency. There is then the risk that the authorities will try to (partly) correct the budgetary position by adjusting the flexible component of the budget: spending on public capital formation. Is this policy - good for meeting conventional IMF-

\footnotetext{
${ }^{3}$ See Balassone and Franco (2000) for an interesting presentation in the context of the Stability and Growth Pact.
} 
type targets - good for society too? What are the long-run growth consequences of such a policy? Does fiscal tightening (fully or partly) based on public investment compression really improve the fiscal position? Do the benefits of fiscal consolidation outweigh the costs of lower public capital investment? The study of the effects of this type of adjustment strategy has been mostly ignored by the macroeconomic literature despite the substantiated evidence available of the central role played by public investment cuts in episodes of fiscal consolidation in industrial and developing countries. ${ }^{4}$

This paper also addresses the feasibility and implications of implementing some of the proposals that have been put forth in the current EU debate on how to relax the fiscal constraints of the Stability and Growth Pact and the Maastricht Treaty. In particular, the paper discusses the adoption of the so-called Golden Rule, the Permanent Balance Rule (Buiter and Grafe, 2004) and the quantitative implications of excluding commercially-run nonfinancial public enterprises or particular public investment projects from standard fiscal stance indicators. The paper examines the long-run returns of permanent and transitory changes in public investment to assess whether capital spending is selfamortizing.

Two features distinguish this model from standard small open economy models. First, in contrast to standard models (Mendoza, 1991; Correia et al., 1995; Senhadji, 1998; Kose, 2002 ; etc.) an economy is presented where decision-making is decentralized into the hands of households and firms. This modeling choice makes it possible to study the effect on enterprise and household behavior of distortionary corporate and personal income taxation. Second, the basic framework is extended to include infrastructure capital as an input in the production function for final output. Infrastructure capital is a composite of public and private infrastructure capital stocks where public and private contents are not perfect substitutes. This setting generalizes existing infrastructure models (see for instance Ambler and Cardia, 1997; Collard, 1997; Dolmas and Huffman, 1997; Glomm and Ravikumar, 1997; Ferreira, 1998; Devarajan, et al., 1998) where the provider of infrastructure is either the government or the private sector - in a model of privatization but not both. Also in contrast with existing literature, public capital is not modeled as a production externality but as a paid input earning a competitive rate of return. Publicly provided infrastructure is modeled as an exogenous forcing process while privately provided infrastructure investment is determined endogenously in the rational expectations equilibrium.

Following recent empirical work on the determinants of sovereign yield spreads ${ }^{5}$, the country is assumed to face an upward-sloping supply function of loans. Existing evidence seems to point that financial markets reward fiscal adjustment. Fiscal consolidation will decrease the stock of public debt and reduce the likelihood of a default on government bonds. Financial markets will react asking for a lower risk premium and interest rates decline. As a result, fiscal contraction will have an expansionary effect on the economy, further improving public accounts. However, if the fiscal contraction is implemented by

\footnotetext{
${ }^{4}$ See for instance, Roubini and Sachs (1989), De Haan et al. (1996), Jonakin and Stephens (1999), Calderón et al. (2003) and IMF (2003).

${ }^{5}$ See for example, Cantor and Packer (1996), Min (1998) and Eichengreen and Mody (2000).
} 
cutting capital spending and the private sector does not take over the government's role, the effect on economic activity and government revenue may be reversed. Ultimately, the net effect of fiscal consolidation efforts based on public investment compression will depend on the interaction of the interest rate response to government debt, the response of output to public infrastructure capital and the response of the private provision of infrastructure to fiscal policy. Taking into account these distinct forces, this paper attempts to provide numerical answers to the posed questions.

A cautionary note delimiting the scope of the paper is in order. The objective of the paper is to compute and analyze the perfect-foresight transitional dynamics of the model economy from 2004 onwards under alternative fiscal policies. Two driving forces induce the dynamics. The first is fiscal policy. The path of fiscal parameters from 2004 onwards is given exogenously, including inter alia public investment in infrastructure. Agents in the model economy are assumed to have perfect foresight over the path of future fiscal policy and respond purposefully to policy incentives. There is no optimal choice of government debt holdings and the government is a debtor that can borrow any amount of resources facing an upward-sloping supply schedule of loans, so that a higher borrowing premium is charged as the government debt-GDP ratio increases. The second force for off-steady state dynamics is explained by the fact that policy experiments based on public investment compression will not ensure the intertemporal sustainability of the fiscal accounts given the current policy stance in Colombia (as of year-end 2003) and the fact that the government has to pay for future unfunded state pension obligations. In absence of some sort of intertemporal balance rule, default is inexorable. To refrain from defaulting, the government is assumed to follow an active policy whereby tax rates are an increasing function of the government debt to GDP ratio. Bohn $(1998,2004)$ shows that a feedback rule whereby the primary surplus to GDP ratio is an increasing function of the initial debt to GDP ratio is a sufficient condition for sustainability. No effort is devoted to model the effect on the transition path of other alternative forcing processes (for instance nominal shocks or terms of trade, world interest rate or world business cycle developments).

This paper proceeds as follows. Section 2 describes the basic structure of the model economy. Section 3 discusses various issues regarding the calibration of deep parameters and the solution method. Section 4 describes the main features of the benchmark policy stance and conducts policy experiments. Section 5 assesses alternative formulas to open space for public infrastructure investment. Section 6 concludes.

\section{THE MODEL}

Consider a small open economy populated by a continuum of identical infinitely lived households, a continuum of identical firms and a government sector composed of the central government and the decentralized public sector. The central government finances sequences of current and capital spending by taxing consumption expenditures and labor and capital income and by issuing domestic debt. The rest of the public sector owns and operates the stock of public infrastructure and sells infrastructure services to finance 
current and capital expenditures and to produce an operating surplus target to improve or alleviate combined public sector finances. The representative firm hires business capital and labor services from households and rents infrastructure capital services from the rest of the government and the private sector to produce the home good. There are two goods in the economy: the home good and the foreign one. The domestic good has final uses in consumption (private and public), investment (private and public) and export. The foreign good, which plays the role of numéraire, can be used for final consumption (private) and investment (private). The relative price of the home good in terms of the foreign one, $p_{t}$ or the real exchange rate loosely speaking, is determined endogenously. The economy faces an imperfect capital market as reflected by an upward-sloping supply curve of debt. The private sector, in attempting to smooth consumption, may borrow abroad on behalf of the public sector. Hence the assumption of government bonds issued exclusively to the domestic market is inconsequential.

The following model economy is expressed in per capita terms and no population growth is allowed. Following convention economy wide, per capita, aggregates are represented by capital letters while variables under the household's control are denoted by lower case letters (except prices). In equilibrium individual choices and the corresponding aggregate magnitudes should be identical.

\subsection{The Production Sector}

There are three reproducible factors of production: infrastructure capital $\mathrm{S}_{\mathrm{t}}$, business capital $\mathrm{K}_{\mathrm{t}}$ and human capital $\mathrm{H}_{\mathrm{t}}$. The stock of infrastructure capital is a composite good obtained from aggregating infrastructure stocks that are publicly $\left(\mathrm{S}_{\mathrm{t}}^{\mathrm{g}}\right)$ and privately $\left(\mathrm{S}_{\mathrm{t}}^{\mathrm{p}}\right)$ provided using a standard constant elasticity of substitution (CES) aggregator:

$\mathrm{S}_{\mathrm{t}}=\lambda^{\mathrm{s}}\left\{\zeta^{\mathrm{s}}\left(\mathrm{S}_{\mathrm{t}}^{\mathrm{p}}\right)^{-v^{\mathrm{s}}}+\left(1-\zeta^{\mathrm{s}}\right)\left(\mathrm{S}_{\mathrm{t}}^{\mathrm{g}}\right)^{-v^{\mathrm{s}}}\right\}^{-\frac{1}{v^{\mathrm{s}}}}$

where $\lambda^{\mathrm{s}}$ is a scale parameter, $\zeta^{\mathrm{s}}$ is a share parameter bound between zero and one and $v^{\mathrm{s}}, v^{\mathrm{s}}>-1$, is a parameter governing the limited substitutability between public and private contents and the corresponding elasticity of substitution is given by $1 /\left(1+v^{\mathrm{s}}\right)$. The privately and publicly provided stocks of infrastructure capital obey the following laws of motion:

$\mathrm{S}_{\mathrm{t}}^{\mathrm{p}}=\left(1-\delta^{\mathrm{s}}\right) \mathrm{S}_{\mathrm{t}-1}^{\mathrm{p}}+\mathrm{I}_{\mathrm{t}}^{\mathrm{hs}}-\Psi^{\mathrm{s}}\left(\mathrm{S}_{\mathrm{t}}^{\mathrm{p}}, \mathrm{S}_{\mathrm{t}-1}^{\mathrm{p}}\right)$

$\mathrm{S}_{\mathrm{t}}^{\mathrm{g}}=\left(1-\delta^{\mathrm{s}}\right) \mathrm{S}_{\mathrm{t}-1}^{\mathrm{g}}+\mathrm{I}_{\mathrm{t}}^{\mathrm{cg}}+\mathrm{I}_{\mathrm{t}}^{\mathrm{rg}}$

where $\delta^{s}$ is the constant rate of depreciation of infrastructure capital, $I_{t}^{\text {hs }}$ is private investment of the domestically produced good in infrastructure and $\mathrm{I}_{\mathrm{t}}^{\mathrm{cg}}\left(\mathrm{I}_{\mathrm{t}}^{\mathrm{rg}}\right)$ represents central (decentralized) government investment of the same type of good in infrastructure. 
Government and rest-of-government investment outlays are exogenous. $\Psi^{\mathrm{s}}\left(\mathrm{S}_{\mathrm{t}}^{\mathrm{p}}, \mathrm{S}_{\mathrm{t}-1}^{\mathrm{p}}\right)$ is an adjustment cost function in gross investment parameterized as a quadratic function and characterized by a single multiplicative parameter $\psi^{\mathrm{s}}$.

Infrastructure services are modeled as private goods, characterized as being rival and excludable, in order to have a private sector willing to provide them. Since scarce resources are used to produce infrastructure services, it is rival - by definition. Since infrastructure is excludable, it is practical to exclude some users and to charge them. Other additional conditions giving rise to infrastructure market failures are also assumed absent (significant externalities, natural monopoly, etc.).

Business capital is owned by households and accumulated according to

$\mathrm{K}_{\mathrm{t}}=\left(1-\delta^{\mathrm{k}}\right) \mathrm{K}_{\mathrm{t}-1}+\mathrm{I}^{\mathrm{k}}\left(\mathrm{I}_{\mathrm{t}}^{\mathrm{hk}}, \mathrm{I}_{\mathrm{t}}^{\mathrm{m}}\right)-\Psi^{\mathrm{k}}\left(\mathrm{K}_{\mathrm{t}}, \mathrm{K}_{\mathrm{t}-1}\right)$

$\delta^{\mathrm{k}}$ is the depreciation rate, $\Psi^{\mathrm{k}}(\bullet)$ represents an internal adjustment cost function in gross investment described by a single parameter $\psi^{\mathrm{k}}$. Gross investment in the business sector is a composite of home and foreign goods which are considered imperfect substitutes according to an Armington aggregator of the CES form:

$$
I_{t}^{k}=I^{k}\left(I_{t}^{h k}, I_{t}^{m}\right)=\lambda^{i}\left\{\zeta^{i}\left(I_{t}^{h k}\right)^{-v^{i}}+\left(1-\zeta^{i}\right)\left(I_{t}^{m}\right)^{-v^{i}}\right\}^{-\frac{1}{v^{i}}}
$$

where $\lambda^{i}$ is a scaling factor, $\zeta^{i}$ is a weight specifying the relative domestic content of business investment and $v^{\mathrm{i}}, v^{\mathrm{i}}>-1$, governs the elasticity of substitution given by $1 /\left(1+v^{i}\right)$.

The remaining factor of production, human capital, can be accumulated in the production process via a learning-by-doing mechanism. As in Arrow (1962) the process of human capital accumulation is a by-product of the production experience. Because the production process causes learning-by-doing, human capital accumulation is the result of a non-deliberate action. Learning-by-doing in period $t$ is assumed to depend on current productive activity,

$$
\mathrm{H}_{\mathrm{t}}=\left(1-\delta^{\mathrm{h}}\right) \mathrm{H}_{\mathrm{t}-1}+\chi \overline{\mathrm{Y}}_{\mathrm{t}}
$$

Learning-by-doing depends on aggregate production $\left(Y_{t}\right.$, please excuse the abuse of notation), implying that households and firms do not internalize the effect of production decisions on human capital accumulation. The effect is a positive externality. Similar ideas are used in Romer (1986) and Collard (1997) for instance. $\delta^{\text {h }}$ is the rate of depreciation of human capital and $\chi, \chi>0$, is the knowledge acquisition rate, the rate at which current productive activity is translated into knowledge. The growth rate of output 
will be higher when resources are allocated by a benevolent social planner who can endogenize the externality.

A homogeneous final home good $Y_{t}$ is produced using business capital, infrastructure capital and labor input. The technology of the firm is Cobb-Douglas:

$$
\mathrm{Y}_{\mathrm{t}}=\lambda^{\mathrm{y}}\left(\mathrm{K}_{\mathrm{t}-1}\right)^{\omega}\left(\mathrm{S}_{\mathrm{t}-1}\right)^{\varphi}\left(\mathrm{N}_{\mathrm{t}} \mathrm{H}_{\mathrm{t}-1}\right)^{1-\omega-\varphi}
$$

The time endowment of the representative household is normalized to unity per period and $N_{t}$ stands for the fraction of the time endowment devoted to work. $\lambda^{y}$ is a scale parameter, $\omega$ represents the capital share parameter in final output and $\varphi$ is an analogous parameter for infrastructure capital. Since all production factors are reproducible and the technology exhibits constant returns to scale in the reproducible factors, the model economy generates endogenous growth. Growth will not come to a halt even if each individual factor, as assumed here, is subject to diminishing returns.

The representative firm seeks to maximize profits by solving a static optimization program:

$$
\max _{\mathrm{N}_{\mathrm{t}}, \mathrm{K}_{\mathrm{t}-1}, \mathrm{~S}_{\mathrm{t}-1}^{\mathrm{p}}, \mathrm{S}_{\mathrm{t}-1}^{\mathrm{g}}} \Pi_{\mathrm{t}}=\mathrm{Y}_{\mathrm{t}}-\mathrm{w}_{\mathrm{t}} \mathrm{N}_{\mathrm{t}} \mathrm{H}_{\mathrm{t}-1}-\mathrm{r}_{\mathrm{t}} \mathrm{K}_{\mathrm{t}-1}-\rho_{\mathrm{t}}^{\mathrm{p}} \mathrm{S}_{\mathrm{t}-1}^{\mathrm{p}}-\rho_{\mathrm{t}}^{\mathrm{g}} \mathrm{S}_{\mathrm{t}-1}^{\mathrm{g}}
$$

where $\Pi_{t}$ is per capita profits, $w_{t}$ is the real wage rate, $r_{t}$ is the rate of return on business capital, $\rho_{\mathrm{t}}^{\mathrm{p}}$ is the rental rate of private infrastructure capital and $\rho_{\mathrm{t}}^{\mathrm{g}}$ is the rental price of publicly provided infrastructure capital services. The optimality conditions deliver the standard condition that the marginal productivity must be equal to the rental price for each factor input:

$$
\begin{aligned}
& \frac{\mathrm{w}_{\mathrm{t}}}{\mathrm{H}_{\mathrm{t}-1}}=(1-\omega-\varphi) \lambda^{\mathrm{y}}\left(\mathrm{K}_{\mathrm{t}-1}\right)^{\omega}\left(\mathrm{S}_{\mathrm{t}-1}\right)^{\varphi}\left(\mathrm{N}_{\mathrm{t}} \mathrm{H}_{\mathrm{t}-1}\right)^{-\omega-\varphi} \\
& \mathrm{r}_{\mathrm{t}}=\omega \lambda^{\mathrm{y}}\left(\mathrm{K}_{\mathrm{t}-1}\right)^{\omega-1}\left(\mathrm{~S}_{\mathrm{t}-1}\right)^{\varphi}\left(\mathrm{N}_{\mathrm{t}} \mathrm{H}_{\mathrm{t}-1}\right)^{1-\omega-\varphi} \\
& \rho_{\mathrm{t}}^{\mathrm{p}}=\varphi \lambda^{\mathrm{y}}\left(\mathrm{K}_{\mathrm{t}-1}\right)^{\omega}\left(\mathrm{S}_{\mathrm{t}-1}\right)^{\varphi}\left(\mathrm{N}_{\mathrm{t}} \mathrm{H}_{\mathrm{t}-1}\right)^{1-\omega-\varphi}\left\{\frac{\zeta^{\mathrm{s}}\left(\mathrm{S}_{\mathrm{t}-1}^{\mathrm{p}}\right)^{-v^{s}-1}}{\zeta^{\mathrm{s}}\left(\mathrm{S}_{\mathrm{t}-1}^{\mathrm{p}}\right)^{-v^{s}}+\left(1-\zeta^{\mathrm{s}}\right)\left(\mathrm{S}_{\mathrm{t}-1}^{\mathrm{g}}\right)^{-v^{s}}}\right\} \\
& \rho_{\mathrm{t}}^{\mathrm{g}}=\varphi \lambda^{\mathrm{y}}\left(\mathrm{K}_{\mathrm{t}-1}\right)^{\omega}\left(\mathrm{S}_{\mathrm{t}-1}\right)^{\varphi}\left(\mathrm{N}_{\mathrm{t}} \mathrm{H}_{\mathrm{t}-1}\right)^{1-\omega-\varphi}\left\{\frac{\left(1-\zeta^{\mathrm{s}}\right)\left(\mathrm{S}_{\mathrm{t}-1}^{\mathrm{g}}\right)^{-v^{s}-1}}{\zeta^{\mathrm{s}}\left(\mathrm{S}_{\mathrm{t}-1}^{\mathrm{p}}\right)^{-v^{s}}+\left(1-\zeta^{\mathrm{s}}\right)\left(\mathrm{S}_{\mathrm{t}-1}^{\mathrm{g}}\right)^{-v^{s}}}\right\}
\end{aligned}
$$

The competitive firm operating a constant-returns technology earns zero profits in equilibrium. 


\subsection{The Representative Household's Problem}

The representative household has preferences over sequences of consumption and leisure and maximizes lifetime utility given by

$$
\begin{aligned}
& \sum_{t=0}^{\infty} \beta^{t} u\left(c_{t}, l_{t}\right)=\sum_{t=0}^{\infty} \beta^{t}\left\{\log \left(c_{t}\right)-\frac{\kappa}{\xi}\left(1-1_{t}\right)^{\xi}\right\} \\
& c_{t}=\left\{\alpha\left(c_{t}^{h}\right)^{-v}+(1-\alpha)\left(c_{t}^{m}\right)^{-v}\right\}^{-\frac{1}{v}}
\end{aligned}
$$

Households draw utility from a composite consumption good $c_{t}$ and from leisure time $1_{t}$. The composite consumption good is itself a combination of two goods treated as imperfect substitutes by a CES Armington aggregator: consumption of home goods $c_{t}^{h}$ and consumption of imported goods $c_{t}^{m}$. The parameter $\alpha$ is a preference relative weight on home goods and $v, v>-1$, determines the elasticity of substitution between home and imported consumption goods. $\beta$ is a subjective discount factor and $\xi$ governs the intertemporal elasticity of substitution in labor supply.

The representative household faces the following flow budget constraint:

$$
\begin{aligned}
d_{t}-\left[B_{t}-\left(1+r_{t}^{\bullet}\right) B_{t-1}\right]=\left(1+r_{t}^{\bullet}\right) d_{t-1} & +p_{t}\left(c_{t}^{h}+i_{t}^{h k}+i_{t}^{h s}\right)+c_{t}^{m}+i_{t}^{m}+M_{t}^{m}+t_{t}+O_{t} \\
& -\left(p_{t}^{\bullet}-p_{t}\right) X_{t}-p_{t}\left(w_{t} n_{t} H_{t-1}+r_{t} k_{t-1}+\rho_{t}^{p} s_{t-1}^{p}\right)+\Psi^{d}\left[d_{t-1}\right]+T R_{t}
\end{aligned}
$$

where $i_{t}^{\text {hk }}\left(i_{t}^{\text {hs }}\right)$ represents investment of the home good in the business (infrastructure) sector and $i_{t}^{m}$ investment of the imported good in the business sector. $t_{t}$ and $O_{t}$ stand for tax and nontax payments to the government. $\mathrm{M}_{\mathrm{t}}^{\mathrm{m}}$ represents intermediate goods imports. These are included here given their quantitative importance but they are not determined endogenously. $\left(p_{t}^{\bullet}-p_{t}\right) X_{t}$ represents profits arising from export broking activities. The representative household buys an exogenously given amount of goods, $X_{t}$, from the representative firm at the domestic price $p_{t}$ and sells it abroad at the exogenous world price $p_{t}^{\bullet}$ per unit of export good, where $p_{t}^{\bullet}$ is the relative price of the export good in terms of the import good, or the terms of trade. To simplify the model economy, both exports and intermediate imports are assumed to remain constant as a share of GDP. $d_{t}$ is foreign debt at the beginning of period $t$ and $r_{t}^{\bullet}$ is the interest rate, in terms of imports, charged on foreign debt. $\mathrm{TR}_{\mathrm{t}}$ represents other time $\mathrm{t}$ lump-sum transfers. $\mathrm{B}_{\mathrm{t}}$ represents holdings of government debt securities issued by either the central government or the rest of the public sector. 
It is well known that the equilibrium dynamics of a small open economy, with asset trading restricted to a noncontingent bond, features a random walk property that prevents the use of local approximation techniques to study the business cycle behavior of the economy around a stationary growth path. To induce stationarity in the equilibrium dynamics this paper introduces convex portfolio adjustment costs which help to pin down the steady state level of foreign debt. $\Psi^{\mathrm{d}}\left[\mathrm{d}_{\mathrm{t}-1}\right]$ represents a quadratic adjustment costs function in the deviation of debt from its steady state level. ${ }^{6}$

Taxes paid by the representative households amounts to:

$\mathrm{t}_{\mathrm{t}}=\tau_{\mathrm{t}}^{\mathrm{c}}\left(\mathrm{p}_{\mathrm{t}} \mathrm{c}_{\mathrm{t}}^{\mathrm{h}}+\mathrm{c}_{\mathrm{t}}^{\mathrm{m}}\right)+\tau_{\mathrm{t}}^{\mathrm{w}} \mathrm{p}_{\mathrm{t}} \mathrm{w}_{\mathrm{t}} \mathrm{n}_{\mathrm{t}} \mathrm{H}_{\mathrm{t}-1}+\tau_{\mathrm{t}}^{\mathrm{k}} \mathrm{p}_{\mathrm{t}}\left\{\left(\mathrm{r}_{\mathrm{t}}-\delta^{\mathrm{k}}\right) \mathrm{k}_{\mathrm{t}-1}+\left(\rho_{\mathrm{t}}^{\mathrm{p}}-\delta^{\mathrm{s}}\right) \mathrm{s}_{\mathrm{t}-1}^{\mathrm{p}}\right\}$

where $\tau_{\mathrm{t}}^{\mathrm{c}}$ is the consumption tax rate, $\tau_{\mathrm{t}}^{\mathrm{k}}$ is the capital income tax rate and $\tau_{\mathrm{t}}^{\mathrm{w}}$ is the labor income tax rate. The household's total time endowment is normalized to unity per period and time spent in employment is subject to

$1=1_{t}+n_{t}$

The accumulation processes of business capital and private infrastructure capital are given by

$\mathrm{k}_{\mathrm{t}}=\left(1-\delta^{\mathrm{k}}\right) \mathrm{k}_{\mathrm{t}-1}+\mathrm{i}^{\mathrm{k}}\left(\mathrm{i}_{\mathrm{t}}^{\mathrm{hk}}, \mathrm{i}_{\mathrm{t}}^{\mathrm{m}}\right)-\Psi^{\mathrm{k}}\left(\mathrm{k}_{\mathrm{t}}, \mathrm{k}_{\mathrm{t}-1}\right)$

$\mathrm{s}_{\mathrm{t}}^{\mathrm{p}}=\left(1-\delta^{\mathrm{s}}\right) \mathrm{s}_{\mathrm{t}-1}^{\mathrm{p}}+\mathrm{i}_{\mathrm{t}}^{\mathrm{hs}}-\Psi^{\mathrm{s}}\left(\mathrm{s}_{\mathrm{t}}^{\mathrm{p}}, \mathrm{s}_{\mathrm{t}-1}^{\mathrm{p}}\right)$

given $\mathrm{k}_{-1}=\mathrm{K}_{-1}$ and $\mathrm{s}_{-1}^{\mathrm{p}}=\mathrm{S}_{-1}^{\mathrm{p}}$. As noted before, gross business investment is a composite of home and foreign goods:

$\mathrm{i}_{\mathrm{t}}^{\mathrm{k}}=\mathrm{i}^{\mathrm{k}}\left(\mathrm{i}_{\mathrm{t}}^{\mathrm{hk}}, \mathrm{i}_{\mathrm{t}}^{\mathrm{m}}\right)=\lambda^{\mathrm{i}}\left\{\zeta^{\mathrm{i}}\left(\mathrm{i}_{\mathrm{t}}^{\mathrm{hk}}\right)^{-v^{\mathrm{i}}}+\left(1-\zeta^{\mathrm{i}}\right)\left(\mathrm{i}_{\mathrm{t}}^{\mathrm{m}}\right)^{-v^{\mathrm{i}}}\right\}^{-\frac{1}{v^{\mathrm{i}}}}$

\subsection{Government}

In per-capita terms, the central government's budget constraint is

$$
B_{t}^{c g}=\left(1+r_{t}^{\bullet}\right) B_{t-1}^{c g}+p_{t}\left(G_{t}^{c g}+I_{t}^{c g}\right)-T_{t}-O_{t}^{c g}-T_{t}^{c g}
$$

where $T_{t}$ is the aggregate version of $t_{t}$. The central government buys home goods and collects revenue from distortionary and lump-sum taxes. Given the initial stock of debt

\footnotetext{
${ }^{6}$ Schmitt-Grohé and Uribe (2003) prove that alternative stationarity-inducing approaches (an endogenous discount factor or a debt-elastic interest-rate premium) yield exactly the same dynamics at business cycle frequencies, at least for the canonical small open economy model.
} 
and the interest rate, the time path of central government debt is implicitly reconstructed from this equation. The rest of government obeys the following budget constraint,

$B_{t}^{r g}=\left(1+r_{t}^{\bullet}\right) B_{t-1}^{r g}+p_{t}\left(G_{t}^{r g}+I_{t}^{r g}\right)-\rho_{t}^{g} S_{t-1}^{g}-O_{t}^{r g}-T R_{t}^{r g}$

where $\mathrm{O}_{\mathrm{t}}^{\mathrm{rg}}$ is an adjustment factor used to target or to replicate the overall surplus observed at this level of government and $\rho_{\mathrm{t}}^{\mathrm{g}} \mathrm{S}_{\mathrm{t}-1}^{\mathrm{g}}$ represents public infrastructure gross user charges. Combined public sector accounts are obtained by consolidating both government levels ('non-financial public sector'). Then $\mathrm{G}_{\mathrm{t}}=\mathrm{G}_{\mathrm{t}}^{\mathrm{cg}}+\mathrm{G}_{\mathrm{t}}^{\mathrm{rg}}, \mathrm{I}_{\mathrm{t}}^{\mathrm{g}}=\mathrm{I}_{\mathrm{t}}^{\mathrm{cg}}+\mathrm{I}_{\mathrm{t}}^{\mathrm{rg}}, \mathrm{O}_{\mathrm{t}}=\mathrm{O}_{\mathrm{t}}^{\mathrm{cg}}+\mathrm{O}_{\mathrm{t}}^{\mathrm{rg}}$, $\mathrm{TR}_{\mathrm{t}}=\mathrm{TR}_{\mathrm{t}}^{\mathrm{cg}}+\mathrm{TR}_{\mathrm{t}}^{\mathrm{rg}}$ and $\mathrm{B}_{\mathrm{t}}=\mathrm{B}_{\mathrm{t}}^{\mathrm{cg}}+\mathrm{B}_{\mathrm{t}}^{\mathrm{rg}}$. Because the initial $\mathrm{B}_{\mathrm{t}}^{\mathrm{rg}}$ is closed to zero (observed holdings of central government bonds in hands of the decentralized sector roughly match the rest-of-government gross debt) and the rest of government is assumed to generate a given surplus - holding everything else constant - the public sector's consolidated stock of (net) debt may be lower than the central government's (gross) stock of debt.

\subsection{Resource Constraints and the Stationarized Economy}

The resource constraint for the home good implies that supply equals demand:

$Y_{t}=Y_{t}=w_{t} N_{t} H_{t-1}+r_{t} K_{t-1}+\rho_{t}^{p} S_{t-1}^{p}+\rho_{t}^{g} S_{t-1}^{g}=C_{t}^{h}+\left(I_{t}^{h k}+I_{t}^{h s}\right)+G_{t}+I_{t}^{g}+X_{t}$

The evolution of the level of net foreign debt, or the current account equation, is determined by:

$D_{t}=\left(1+r_{t}^{\bullet}\right) D_{t-1}+C_{t}^{m}+I_{t}^{m}+M_{t}^{m}-p_{t}^{\bullet} X_{t}+\Psi^{d}\left[D_{t-1}\right]$

The model economy is non-stationary because there is endogenous growth, as human capital can be accumulated without bound. It can be shown that the economy's rate of growth is determined by the rate of human capital accumulation,

$$
\eta_{\mathrm{t}}=\frac{\mathrm{H}_{\mathrm{t}}}{\mathrm{H}_{\mathrm{t}-1}}
$$

where $\eta_{t}$ is the gross rate of growth. To induce stationarity the common trend is removed by dividing all growing variables in the model by $H_{t}$. The symbol $\wedge$ represents transformed variables. For instance,

$$
\hat{\mathrm{k}}_{\mathrm{t}}=\frac{\mathrm{k}_{\mathrm{t}}}{\mathrm{H}_{\mathrm{t}}} \quad \hat{\mathrm{K}}_{\mathrm{t}}=\frac{\mathrm{K}_{\mathrm{t}}}{\mathrm{H}_{\mathrm{t}}}
$$


The transformed economy ${ }^{7}$ possesses a well-defined steady state as long as nonconverging paths for the public finances are ruled out. To guarantee debt sustainability, the following reaction function of the fiscal authority describing the behavior of taxes is a sufficient condition for averting explosive paths:

$$
\left[\begin{array}{c}
\tau_{t}^{\mathrm{c}} \\
\tau_{\mathrm{t}}^{\mathrm{k}} \\
\tau_{\mathrm{t}}^{\mathrm{w}}
\end{array}\right]=\left[\begin{array}{c}
\tau^{\mathrm{c}} \\
\tau^{\mathrm{k}} \\
\tau^{\mathrm{w}}
\end{array}\right] \cdot \exp \left(\frac{\hat{\mathrm{B}}_{\mathrm{t}-1}^{\mathrm{cg}}}{\hat{\mathrm{Y}}_{\mathrm{t}-1}}-\frac{\hat{\mathrm{B}}^{\mathrm{cg}}}{\hat{\mathrm{Y}}}\right)
$$

where $\hat{\mathrm{B}}^{\mathrm{cg}} / \hat{\mathrm{Y}}$ is the steady state central government debt to GDP ratio.

Finally, the economy faces an upward-sloping supply schedule for debt expressed as a two-component aggregate borrowing rate composed of a constant world interest rate $\left(\mathrm{r}^{\left.\boldsymbol{}^{*}\right)}\right.$ and a variable premium $\left(\mathrm{z}_{\mathrm{t}}\right)$. The borrowing premium depends on the central government debt to GDP ratio and is assumed to reflect the capital markets' assessment of the economy's ability to service its debt. This is why the same rate is charged to both government and private sector borrowing. The borrowing rate is of the form:

$$
\mathrm{r}_{\mathrm{t}}^{\bullet}=\mathrm{r}^{\bullet}+\mathrm{z}_{\mathrm{t}}=\mathrm{r}^{\bullet}+\mathrm{z} \cdot \exp \left(\varepsilon \cdot\left[\frac{\hat{\mathrm{B}}_{\mathrm{t}-1}^{\mathrm{cg}}}{\hat{\mathrm{Y}}_{\mathrm{t}-1}}-\frac{\mathrm{B}^{\mathrm{cg}}}{\hat{\mathrm{Y}}}\right]\right)
$$

where $\varepsilon$ is the debt/GDP semi-elasticity of the borrowing premium.

\section{CALIBRATION AND SOLUTION METHOD}

\subsection{Parameter Values and the Structure of the Economy}

The model economy is parameterized in such a way that its long-run features mimic the observed structure of the Colombian economy in 2003. In other words, if the 2003 fiscal policy stance is assumed to remain unchanged, the long-run structure and growth performance of the model economy will be like that observed in $2003 .{ }^{8}$ In particular, in the steady state of the model economy the expenditure side of the national income accounts coincides with the 2003 observed structure: household consumption represents $62 \%$ of GDP and total private investment $11.5 \%$ of GDP, of which $2.74 \%$ of GDP is investment in infrastructure, according to Departamento Nacional de Planeación (DNP) data. The public sector represents $26.8 \%$ of GDP, made up of central government purchases (16\% of GDP), the rest of the public sector's expenditures ( $8 \%$ of GDP) and

\footnotetext{
${ }^{7}$ With logarithmic preferences there is no need to transform the subjective discount factor.

8 The correction of existing macroeconomic imbalances requires the use of lump-sum adjustments. Specifically, the 2003 fiscal policy stance is made sustainable through lump-sum taxation.
} 
public infrastructure investment. Public investment in infrastructure ${ }^{9}$ amounts to $2.8 \%$ of GDP made up of central government investment ( $0.6 \%$ of GDP) and decentralized government infrastructure outlays $(2.2 \%$ of GDP). The model economy also matches the average level and composition of imports. Total imports amount to $18.5 \%$ of GDP. This is composed of import of consumption goods $(3.7 \%$ of GDP), capital goods $(6.1 \%$ of GDP) and intermediate goods (8.7\% of GDP).

The structure of central government tax revenue is similar to the one observed in Colombia. Total tax revenue in the model amounts to $14.1 \%$ of GDP, which is very close to what is observed in the data. This percentage includes consumption taxes $(7.4 \%$ of GDP), labor income taxes ( $0.6 \%$ of GDP) and capital income taxes (6.1\% of GDP). The split in the income taxes between labor and capital income taxes is based on information from DIAN on tax withholding figures organized by type of taxpayer. The model's gross debt-GDP ratio of the central government is set at $54 \%$, which corresponds to the observed ratio by year-end 2003 (source: CONFIS). The net debt-GDP ratio of the rest of the public sector is set at $0 \%$ of GDP. This is roughly consistent with CONFIS data estimating the level of the combined public sector ('non-financial public sector') gross debt to be $68 \%$ of GDP and a combined net debt (excluding holdings of central government bonds in the portfolio of the rest of the public sector) to be close to $54 \%$ of GDP. The model's external debt-GDP ratio is set at 50\% of GDP (source: Banco de la República).

The interest rate charged to private and public borrowers is the sum of two components: an exogenously given world interest rate proxied by the U.S. interest rate $\left(r^{\bullet \bullet}=4 \%\right.$, see Prescott, 1986; Backus et al., 1994) and a borrowing premium measured by the JP Morgan's Latin America Eurobond Index spread. The average spread for Colombia was 420 basis points over the last quarter of $2003(\mathrm{z}=0.042)$. The semi-elasticity of the borrowing spread with respect to the debt-GDP ratio is set at $\varepsilon=0.3$ as a reasonable compromise. ${ }^{10}$

An expression for $\beta$ can be obtained from the first order conditions, evaluated at the steady state, relating interest and subjective discount rates:

\footnotetext{
${ }^{9}$ The public sector invests in physical infrastructure $2.8 \%$ of GDP, which corresponds to the average level during the 1994-2002 period (includes investments in transport, energy, telecom and oil sectors). Because there is no data available to disentangle the contributions of the central government and the rest of the public sector to this number, public investment in infrastructure is split using NIPA's contributions to gross public capital formation. The average contribution of the central government is $23 \%$ during the period 1994-2001. In consequence, under the benchmark policy stance the central government is estimated to invest $0.6 \%$ of GDP in infrastructure and the rest of the public sector invests the remaining $2.2 \%$ of GDP.

${ }^{10}$ In empirical studies the debt variable is generally defined as total external debt and not as total public debt. Min (1998) estimates $\varepsilon=1$ and Cantor and Packer (1996) find no significant relation between the debt-GDP ratio and yield spreads. Eichengreen and Mody (2000) estimate $\varepsilon=1.3$. Hilscher and Nosbusch (2004) define debt as total government external debt and from their point estimate it is possible to calculate $\varepsilon=0.02$, approximately.
} 
$\beta=\frac{\eta}{1+r^{\bullet \bullet}+z}$

where $\eta, \eta=1.017$, is the 2003 per-capita gross rate of growth, which is consistent with the observed rate of growth of GDP of $3.84 \%$ in 2003, using an annual growth rate of the population aged 15-64 of 2.1\% (source: DANE). This implies $\beta=0.94$. Note that the model is calibrated so that the length of a model period is one year.

Ostry and Reinhart (1992) estimate the elasticity of substitution between nontradables and importables in consumption to be 1.28 for a sample of developing countries. I take this value as a proxy for the elasticity of substitution between $\hat{\mathrm{C}}_{t}^{\mathrm{h}}$ and $\hat{\mathrm{C}}_{t}^{\mathrm{m}}$. This implies a value for $v$ equal to -0.22 . From the equilibrium versions of the household's first order conditions for $\hat{c}_{t}^{\mathrm{h}}$ and $\hat{\mathrm{c}}_{\mathrm{t}}^{\mathrm{m}}$, evaluated at the steady state, and setting relative prices equal to unity in the steady state, an expression for $\alpha$ can be obtained:

$$
\alpha=\frac{1}{1+\left(\frac{\mathrm{C}_{\mathrm{va}}^{\mathrm{m}}}{\mathrm{C}_{\mathrm{va}}^{\mathrm{h}}}\right)^{1+v}}
$$

where $\mathrm{C}_{\mathrm{va}}^{\mathrm{m}}$ and $\mathrm{C}_{\mathrm{va}}^{\mathrm{h}}$ are defined as the average shares of imported consumption goods and home consumption goods in total value added, respectively. Given the assumed structure of the economy, all the required information on the right-hand side is known. Then set $\alpha=0.883$. Lacking specific evidence on the elasticity of substitution between home and imported goods in investment, I use the same estimate as for the consumption elasticity. This implies $v^{i}=-0.22$.

The first order conditions for $\hat{i}_{t}^{h k}$ and $\hat{i}_{t}^{m}$, evaluated at the steady state, yield an expression for $\zeta^{i}$ in terms of known magnitudes:

$$
\zeta^{\mathrm{i}}=\frac{1}{1+\left(\frac{\mathrm{I}_{\mathrm{va}}^{\mathrm{m}}}{\mathrm{I}_{\mathrm{va}}^{\mathrm{hk}}}\right)^{1+\mathrm{v}^{\mathrm{i}}}}
$$

Set $\zeta^{i}=0.337$. Exploiting the specification of the Armington aggregator calibrate $\lambda^{i}=1.868$ from the following expression

$$
\lambda^{\mathrm{i}}=\frac{\mathrm{I}_{\mathrm{va}}^{\mathrm{k}}}{\left\{\zeta^{\mathrm{i}}\left(\mathrm{I}_{\mathrm{va}}^{\mathrm{hk}}\right)^{-v^{\mathrm{i}}}+\left(1-\zeta^{\mathrm{i}}\right)\left(\mathrm{I}_{\mathrm{va}}^{\mathrm{m}}\right)^{-v^{\mathrm{i}}}\right\}^{-\frac{1}{v^{\mathrm{i}}}}}
$$


In addition, using a rate of depreciation of infrastructure capital of $4 \%$ (Collard, 1997), i.e. $\delta^{s}=0.04$, and the steady state version of the law of motion for the stock of infrastructure capital, it is possible to calculate the ratios of private $\left(\mathrm{S}_{\mathrm{va}}^{\mathrm{p}}\right)$ and public $\left(\mathrm{S}_{\text {va }}^{\mathrm{g}}\right)$ infrastructure to GDP:

$\mathrm{S}_{\mathrm{va}}^{\mathrm{p}}=\left(\frac{\eta}{\eta+\delta^{\mathrm{s}}-1}\right) \mathrm{I}_{\mathrm{va}}^{\mathrm{hs}}$

$\mathrm{S}_{\mathrm{va}}^{\mathrm{g}}=\left(\frac{\eta}{\eta+\delta^{\mathrm{s}}-1}\right) I_{\mathrm{va}}^{\mathrm{g}}$

Knowing that in Colombia the stock of total physical capital to GDP ratio is 2.63 (Loayza et al., 2003) I can calculate the ratio of the stock of business capital to output as

$\mathrm{K}_{\mathrm{va}}=2.63-\mathrm{S}_{\mathrm{va}}^{\mathrm{p}}-\mathrm{S}_{\mathrm{va}}^{\mathrm{g}}=2.63-\mathrm{S}_{\mathrm{va}}$

Now using the law of motion for the stock of business capital, its rate of depreciation can be computed from following expression:

$\delta^{\mathrm{k}}=1-\eta+\eta \frac{\mathrm{I}_{\mathrm{va}}^{\mathrm{k}}}{\mathrm{K}_{\mathrm{va}}}$

Thus, set $\delta^{\mathrm{k}}=0.037$.

Tax rates, consistent with the assumed structure of tax collections and the model's tax definitions, are set at:
$\tau^{\mathrm{c}}=12 \%$
$\tau^{\mathrm{k}}=26.4 \%$
$\tau^{\mathrm{w}}=0.9 \%$

Based on the properties of the constant returns to scale Cobb-Douglas technology, the parameter $\omega$ is calibrated from the following expression:

$\omega=\frac{\mathrm{r}}{\eta} \mathrm{K}_{\mathrm{va}}$

where $\mathrm{r}$ is the gross rate of return to business capital calculated, in turn, from the optimality condition for $\hat{\mathrm{k}}_{\mathrm{t}}$ of the household's optimization problem. Set $\omega=0.24$. By the same type of argument, the technology parameter $\phi$ must satisfy

$\phi=\frac{\rho^{\mathrm{p}}}{\eta} \mathrm{S}_{\mathrm{va}}^{\mathrm{p}}+\frac{\rho^{\mathrm{g}}}{\eta} \mathrm{S}_{\mathrm{va}}^{\mathrm{g}}$ 
where $\rho^{\mathrm{p}}$, the gross rate of return to private infrastructure capital, can be obtained from the steady state version of the optimality condition for $\hat{s}_{t}^{p}$. By assuming $\rho^{p}=\rho^{\mathrm{g}}, \phi$ is set equal to 0.147 . This figure is very close to the value of 0.138 for the infrastructure elasticity of GDP estimated by Calderón and Servén (2005) for a sample of developing countries where the infrastructure variable is proxied by a synthetic index of physical infrastructure (telecom/power/roads). ${ }^{11}$

The values of the parameters $\zeta^{\mathrm{s}}$ and $\lambda^{\mathrm{s}}$ are obtained from the first order condition for $\mathrm{S}_{\mathrm{t}-1}^{\mathrm{p}}$ and the CES aggregator of infrastructure. In the absence of empirical evidence on the elasticity of substitution between private and public infrastructure stocks $v^{\mathrm{s}}$ is set at 3.0, which implies a relatively low elasticity of substitution $(0.25)$.

$$
\begin{aligned}
& \frac{\rho^{\mathrm{p}}}{\eta} \mathrm{S}_{\mathrm{va}}^{\mathrm{p}}=\phi\left\{\frac{\zeta^{\mathrm{s}}\left(\mathrm{S}_{\mathrm{va}}^{\mathrm{p}}\right)^{-v^{\mathrm{s}}}}{\zeta^{\mathrm{s}}\left(\mathrm{S}_{\mathrm{va}}^{\mathrm{p}}\right)^{-v^{\mathrm{s}}}+\left(1-\zeta^{\mathrm{s}}\right)\left(\mathrm{S}_{\mathrm{va}}^{\mathrm{g}}\right)^{-v^{\mathrm{s}}}}\right\} \\
& \lambda^{\mathrm{s}}=\frac{\mathrm{S}_{\mathrm{va}}}{\left\{\zeta^{\mathrm{s}}\left(\mathrm{S}_{\mathrm{va}}^{\mathrm{p}}\right)^{-v^{\mathrm{s}}}+\left(1-\zeta^{\mathrm{s}}\right)\left(\mathrm{S}_{\mathrm{va}}^{\mathrm{g}}\right)^{-v^{\mathrm{s}}}\right\}^{-\frac{1}{v^{s}}}}
\end{aligned}
$$

Then set $\zeta^{\text {s }}$ equal to 0.48 and $\lambda^{\text {s }}$ equal to 2.0. Parameter sensitivity analysis is applied to assess how the degree of substitutability in the provision of infrastructure services influences the behavior of the economy.

Next, the preference parameter $\xi$ governing the intertemporal elasticity of substitution in labor supply is set equal to 1.6 , a number consistent with an elasticity of 1.7 adopted by Greenwood et al. (1988) as a reasonable compromise. The steady state level of employment is set at $\mathrm{N}=1 / 3$, which is a standard choice in the literature. The parameter $\kappa$ is set equal to 6.03 based on the first order condition for $n_{t}$ :

$$
\kappa=\left(\frac{1-\tau^{\mathrm{w}}}{1+\tau^{\mathrm{c}}}\right)(1-\omega-\phi) \alpha \mathrm{N}^{-\xi}\left(\mathrm{C}_{\mathrm{va}}^{\mathrm{h}}\right)^{-1-v}\left\{\alpha\left(\mathrm{C}_{\mathrm{va}}^{\mathrm{h}}\right)^{-v}+(1-\alpha)\left(\mathrm{C}_{\mathrm{va}}^{\mathrm{m}}\right)^{-v}\right\}^{-1}
$$

Finally, $\chi$ and the scale parameter $\lambda^{y}$ were chosen so that the model's steady state output is normalized to $\hat{Y}=\hat{Y}=100$. Set $\chi$ equal to 0.0006 , which satisfies the law of

\footnotetext{
${ }^{11}$ The existing empirical work for Colombia has followed Aschauer (1989) who modeled the aggregate production function with public infrastructure capital as an input. Sánchez (1994) and Cárdenas et al. (1995) report point estimates ranging from 0.10 to 1.59 . Though our parameter value is at the lower end of this broad range, these econometric results are not taken into consideration as they are subject to criticism in various ways (implausibly large marginal productivity of public capital, specification problems, simultaneity bias, theoretical underpinning, etc.).
} 
motion for the stock of human capital, assuming a constant depreciation rate of $4 \%$, i.e. $\delta^{\mathrm{h}}=0.04$ (Collard, 1997),

$\chi=\frac{1-\frac{\left(1-\delta^{\mathrm{h}}\right)}{\eta}}{\hat{\mathrm{Y}}}$

From the specification of the production technology the scaling parameter $\lambda^{\mathrm{y}}$ is set at 30.15. Table 1 summarizes baseline parameter values used hereinafter.

\subsection{Solution Method}

There is no analytical solution to the described optimization problem. To obtain an approximate solution, the system of first order conditions is linearized around its deterministic steady state and the resulting multivariate linear rational expectations equation system is solved numerically with the Quadratic Determinantal Equation method developed by Binder and Pesaran (1995, 1997). Before linearizing the system of equations describing the equilibrium, I introduced a change of variables to express all macro aggregates (except output) as a fraction of GDP. As a consequence, the numerical method is adjusted to provide a solution in terms of the levels of the system's redefined endogenous variables and not in terms of their deviations from steady state.

Let $X_{t}$ be the vector of endogenous variables and $\wp_{t}$ the vector of policy and exogenous variables at time $\mathrm{t}$ defined as follows: 


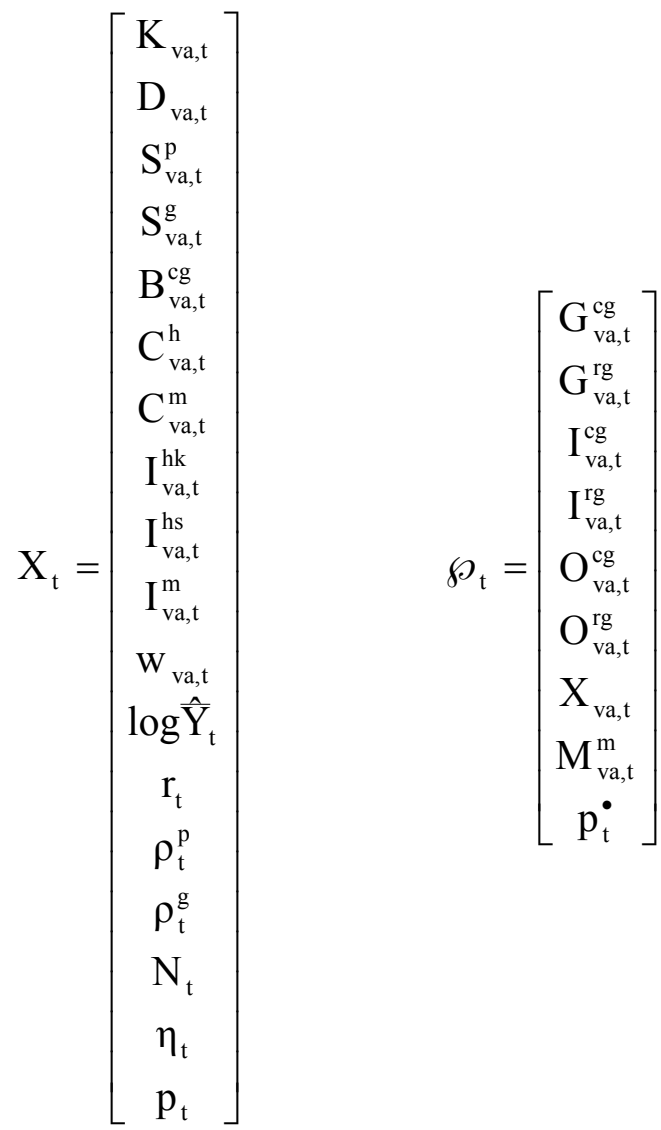

where the subscript "va" means that the corresponding variable has been expressed as a fraction or share of GDP (for instance, $K_{v a, t}=\hat{K}_{t} / \hat{Y}_{t}$ ). The solution is a first order difference equation system of the form:

$\mathrm{X}_{\mathrm{t}}=$ constant $+\mathrm{C} \mathrm{X}_{\mathrm{t}-1}+\mathrm{D} \wp_{\mathrm{t}+1}+\mathrm{F} \wp_{\mathrm{t}}$

where the arrays: constant, C, D and F are complicated functions of the model's parameters. Given the trajectory of the policy and exogenous variables $\left(\{\wp\}_{\mathrm{t}=2004}^{\mathrm{t}=2100}\right)$ and the starting point $\left(\mathrm{X}_{2003}\right)$, it is possible to compute the equilibrium dynamics of the economy from 2004 onwards.

\section{SIMULATION RESULTS}

\subsection{Baseline Policy Stance and Benchmark Economy}

Before conducting policy experiments, it is necessary to spell out the current fiscal policy stance and describe how it is modified under alternative experimental setups. Based on year 2003 data, the "inherited" policy stance is characterized by the following salient features (see Table 2 for completeness). 
As in the data (CONFIS, 2004), central government revenues amount to $15.6 \%$ of GDP made up of non-tax revenues (1.5\% of GDP) and tax revenues ( $14.1 \%$ of GDP). Consistent with the tax collection figure, with the observed revenue composition and with the model's tax definitions, the baseline consumption tax rate is calibrated at $12 \%$, the capital income tax rate at $26.4 \%$ and the labor income tax rate at $0.9 \%$. On the other hand, central government primary expenditures represent $16.6 \%$ of GDP of which approximately $0.6 \%$ of GDP is classified as capital spending. As is apparent, the central government primary balance exhibits a deficit of $1 \%$ of GDP and a with-interest deficit of $5.5 \%$ of GDP, revealing the burden of a debt of 54\% of GDP.

Decentralized government accounts are built on the basis of the model economy specification and data. The rest of the public sector invests $2.2 \%$ of GDP in infrastructure and exhibits an overall surplus of $2.4 \%$ of GDP. This brings the combined overall public sector balance to a deficit equivalent to 3.1 of GDP. Given interest rate and growth rate prospects, if the described fiscal policy parameters remain unchanged, the current stance is unsustainable. It is made sustainable by appropriate lump-sum transfers to the government. By construction, if this adjusted fiscal policy stance is assumed to remain forever, the economy will remain or converge to its steady-state equilibrium, as described in the preceding section. ${ }^{12}$ Let us assume this is the case.

The preceding portrait of the public finances does not offer a complete panorama, however. The current expenditures of the central government are assumed to remain constant in the future (at 16\% of GDP) which is indeed a bad assumption. This assumption does not take into account the major source of concern with respect to the evolution of the public finances: future unfunded state pension liabilities. Figure 1 displays the path of expected deficits of the state social security system (solid line) as calculated by the DNP. In 2004 the pension deficit is approximately 3.1\% of GDP. From then on it will increase steadily up to a peak of $6.2 \%$ of GDP in 2014 and then decrease gradually. Nevertheless, deficits will remain over 3\% of GDP up until year 2040. Even disregarding the "inherited" fiscal imbalance, it is clear that unfunded pension liabilities will represent a major source of fiscal stress and intertemporal solvency problems in the years ahead.

The expected path of current expenditures of the central government is constructed by adding to the baseline expenditures path (i.e. 16\% of GDP from 2003 onwards) the amount associated with the dotted line in Figure 1, which corresponds to the difference between the estimated future deficits of the state pension system and the amount of pension transfers already incorporated into the 2003 central government budget (approx. $3 \%$ of GDP).

Holding constant other fiscal policy parameters, the new path of expenditures will push the economy off its steady state balanced growth trajectory and lead to an explosive growth of the government debt, eventually violating the transversality condition (NoPonzi Game condition). The question is how to finance the future path of government

\footnotetext{
${ }^{12}$ Keep in mind that the correction of this part of Colombia's fiscal imbalance and well as its effect on economic behavior are not being addressed in the ensuing policy experiments.
} 
expenditures, restoring fiscal solvency. This paper assesses two alternatives $\left.{ }^{13}: 1\right)$ taxfinanced pension transfers, hereinafter referred to as the tax-financed scheme or scenario and 2) additional pension payments financed by public capital spending cutbacks.

\subsection{Experiment 1: Distortionary Tax Financing}

This section offers an exposition of the macroeconomic effects of using distortionary taxation to finance future pension outlays. In stricto sensu, the financing strategy uses a combination of debt and tax financing. The experiment is set up so that the economy initially issues new debt to pay for growing pension transfers and then adjusts tax rates in response to changes in the central government debt to GDP ratio to ensure the sustainability of the financing scheme. Obviously, the transition path of the economy will depend on the aggressiveness with which policymakers adjust taxes. The responsiveness of taxes to the debt-GDP ratio controls the pace at which debt accumulates along the transitional dynamics and is assumed equal across experiments. ${ }^{14}$

From the solution of the model - the recursive equilibrium law of motion - it is possible to compute from 2004 onwards the macroeconomic dynamics generated by the new path of the exogenous variables. The results of the numerical simulation for the first decade are reported in Figures 2A (macroeconomic aggregates), 2B (fiscal performance) and 2C (fiscal policy). All depicted variables, except rates and relative prices, are expressed as a share of GDP.

The tax financing scheme has sizeable effects on relative prices and quantities. There will be a persistent trend toward real exchange rate appreciation and in the national income and product accounts higher public spending is partly accommodated at the expense of lower private consumption and total investment. Since public investment, as a share of GDP, is assumed to remain constant in this experiment, the fall in total investment, as a share of GDP, is mainly explained by a reduction of private investment in both the business sector and the infrastructure sector. The private sector will be crowded out by the expected pension outlays.

Pension payments initially financed by issuing additional debt will tend to stimulate economic activity judging by the fact that the growth rate will increase somewhat relative to the outcome for year 2003 (3.84\%). This expansionary outcome may persuade policymakers to delay adjustment as long as capital markets are willing to finance such deficits. But as soon as debt starts growing, interest rate and tax rate hikes will rapidly cool down the economy. Despite substantial tax rate and tax collection increases, central government debt will increase from 54 percent of GDP in 2003 to $75 \%$ of GDP over the next 10 -year period.

\footnotetext{
${ }^{13}$ Feasible alternatives are also the reduction of current expenditures and a pension reform reducing pension obligations. If taken into account, they only imply a new trajectory for the exogenous path of future expenditures.

${ }^{14}$ In all experiments the debt-GDP semi-elasticity of the different tax rates is unitary.
} 
For the sake of comparison, Figures 3A and 3B depict "official" forecasts recently published by the Ministry of Finance (Ministerio de Hacienda y Crédito Público, 2004) and IMF (2004b), respectively. Though none of these pieces provide a clear description of the policies being implemented, they foresee a significant consolidation effort with no apparent growth sacrifice. This comparison provides an opportunity to assess whether the proposed approach to policy evaluation provides further insights into understanding the relation between policies and economic performance vis-à-vis the perspective provided by the Financial Programming approach. Interestingly, the two approaches provide fundamentally opposing views on the economy's future growth path.

The Ministry of Finance recently released its Medium-Term Economic Program. This report provides medium-term baseline projections (2004-2020) for the economy's main macroeconomic aggregates, assuming the continuation of current policies (no new reforms are spelled out). The report assumes that from 2004 onwards the economy's GDP will grow at a rate of $4 \%$ per annum retaking, for no apparent economic reason, its longrun path of economic growth (see Figure 3A). On the expenditure side of the national income and product accounts, growth is fueled by private consumption and investment in sharp contrast to predictions of the intertemporal model. The share of private consumption and investment in GDP will increase from $62 \%$ to $64 \%$ for the former and from $13.3 \%$ to $17.5 \%$ for the latter. The space gained by consumers and private investors in GDP is at the expense of the public sector whose share will shrink by $6 \%$ of GDP over the next 15 years with no noticeable growth impact. Hence public debt will fall from 54\% of GDP in 2003 to $42 \%$ fifteen years later. In summary, in the authorities' view, the fiscal position will improve "endogenously" thanks to a rapid resumption of private economic activities and historical growth trends, leaving little trace of what was once considered a sustainability concern.

The IMF (2004b) also provides baseline projections and similar developments are forecast for the economy (see Figure 3B). Its projections assume that the authorities can sustain a combined public sector primary surplus of $2.7 \%$ of GDP per year starting in 2005. This would require an adjustment of approximately $3.8 \%$ of GDP in the combined primary surplus over the 2003 stance (including new pension obligations, in average $2.5 \%$ of GDP in the near future). If an adjustment of this magnitude is assumed, the Fund's debt sustainability analysis "finds" ("assumes") that, under all stress tests, the public accounts are sustainable. However, the report does not explain how to achieve such an adjustment in the very short run with no apparent growth effect (the economy's growth rate is constant at $4 \%$ per year in the next six years).

\subsection{Experiment 2: Public Investment Cutbacks}

Both the government's Economic Program and the Fund's Third Review Report anticipate substantial fiscal consolidation efforts in the short run: the first requires a reduction of government spending of $6 \%$ of GDP and the second an improvement in the combined primary balance of $3.8 \%$ of GDP. In both, the distinction between capital and current expenditures is irrelevant because the economy is assumed to grow at its historically average rate, independently of how fiscal policy unfolds. This section uses 
the intertemporal framework to assess the growth toll and other macroeconomic consequences of a fiscal adjustment (at most of $2.8 \%$ of GDP - because this is what the public sector spends on average in infrastructure) based on public investment compression.

The first experiment conducted in this section assumes that central government capital spending is pared to nothing. The central government, in fact, invests very little in infrastructure ( $0.6 \%$ of GDP) so minimum effects on public finances should be expected. The baseline policy stance is modified to incorporate no central government investment spending (see Figure 4C). Under this financing scheme, authorities initially reduce capital spending to finance additional pension transfers, but given their relative magnitudes, soon have to resort to new debt placements and subsequent tax increases. The difference between the setup of this experiment and the one discussed in the preceding section is the permanent shut down of the central government investment activity to contribute to fiscal adjustment.

The behavior of the economy is shown in Figures 4A (macroeconomic aggregates), 4B (fiscal performance) and 4C (fiscal policy). The behavior of the economy under the "taxfinanced" strategy, depicted by dashed lines, is included for comparison. The central government primary surplus effectively improves by approximately $0.6 \%$ of GDP in the very short run, giving the illusion that this type of adjustment works, but after seven years or so its time path is very similar to the one observed under the "tax-financed" scheme. This implies that public investment contraction is ineffective to improve the fiscal position in the medium term and to restore fiscal solvency in the long run. The reason is that investment compression hits harder economic growth than a "tax-financed" program, despite reigning lower interest and tax rates (in the medium term).

There seems to be an improvement in the central government overall budget balance relative to the "tax-financed" scenario over the 10-year horizon illustrated in Figure 4B. Nonetheless, this effect will ultimately prove to be transient too. By year 2030 (not shown in the figure) the time path of the overall budget balance is indistinguishable from the one observed under the "tax-financed" alternative. It is worth mentioning that investment compression may cause a long lasting improvement in the decentralized government sector finances and therefore, in the combined accounts, thanks to a substantial increase in the overall cost of public infrastructure services, reflecting the shortage of infrastructure capital. The private sector does not fill the gap in the provision of infrastructure services left by the withdrawal of the central government and, on the contrary, finds it optimal to reduce slightly infrastructure spending.

In the second experiment of this section the decentralized public sector contributes to the process of fiscal adjustment by reducing capital spending. In addition to a reduction in capital expenditures at the central government level equal to $0.6 \%$ of GDP, the rest-ofgovernment capital expenditures are gradually pared down from a level of $2.2 \%$ of GDP to nothing over the course of several years (see Figure 5C) at a pace dictated by expected pension payments. This adjustment is not big enough to meet all funding needs. 
Additional financing requirements are satisfied through the issuance of debt and tax increases.

The behavior of the model economy conditional on the described policy is depicted in Figures 5A (macroeconomic aggregates), 5B (fiscal performance) and 5C (fiscal policy). Again, the behavior of the model economy under the tax financing scheme (dashed lines), is included for comparison. While public investment is falling in total by $2.8 \%$ of GDP, the time path of total investment exhibits a greater deterioration $(4.8 \%$ of GDP after a decade and $5.2 \%$ after three decades, both measured relative to the "tax-financed" scenario) accounted for by lower private investment both in business capital and in infrastructure capital. It is interesting to confirm that the role of the government in providing infrastructure services is not taken over by the private sector. Private investment in infrastructure tends to decline in tandem with public investment. As a result, the economy's average growth rate falls almost by $0.4 \%$ after a decade and by $1 \%$ in the long-run. The negative direct effect of public investment cuts on growth outweighs the expansionary effect that a fiscal adjustment plan (resorting to investment cuts) exerts though lower interest rates.

In order to deliver a lower capital stock in the steady state and to accommodate lower investment activity on the expenditure side of the national product accounts, private consumption expenditures increase as a share of GDP. Tax collections benefit from the recomposition of GDP toward consumption but this effect is not strong enough to compensate for deteriorated growth prospects. Interestingly, the economy with no public capital investment ends up charging almost the same tax rates as in the "tax-financed" program, but revenue performance is far more dismal (see Figure 5C). Tax revenue drops by $1.4 \%$ of GDP approximately after a decade relative to the benchmark.

This experiment reconfirms our previous findings: the improvements in the central government primary and overall balances are transitory and public investment compression is incapable of bringing public finances toward solvency. In contrast to our previous finding on the effect on decentralized government finances, this experiment finds that their improvement is ephemeral too. But, as in the previous experiment, the source of that improvement can be found in a substantial increase in the rental price of public infrastructure capital. According to Figure 5D the user cost of public infrastructure capital $\left(\rho_{\mathrm{t}}^{\mathrm{g}}\right)$ will increase from $15.1 \%$ in 2003 to $29 \%$ two decades later and to $36 \%$ in the long-run. In contrast, under the "tax-financed" scheme, the long-run rental price of public infrastructure services will converge to $14 \%-15 \%$.

To summarize, an established empirical literature has found that governments in developing as well as in developed countries have attempted to sustain or regain sound budgetary positions by reducing public investment. The experiments conducted in this section show that this type of adjustment has a transient effect on medium-term fiscal deficits and a negligible impact on long-run solvency. However, its cost, in terms of foregone growth, could be substantial. 


\subsection{Sensitivity Analysis}

To compensate for the lack of direct parameter estimates for Colombia, the calibration procedure has exploited additional sources of information as is the existing literature on developing countries. Even so, in a number of cases the calibration criterion is simply that model parameter choices be reasonable on the basis of other independent estimates. To assess the reliability of the parameterization strategy and robustness of the simulated results, these parameter values are perturbed to perform a sensitivity analysis. Since these parameters values are generally unknown, instead of evaluating the effect of small changes around baseline values, the sensitivity analysis is conducted for extreme parameter settings to determine the conditions under which conclusions may possibly vary. This section investigates the sensitivity of the results to five parameters for which there is little knowledge or reliable data. The parameters are: 1) the elasticity of substitution between public and private infrastructure, governed by $v^{\mathrm{s}} ; 2$ ) the elasticity of substitution between home and imported investment goods, controlled by $v^{\mathrm{i}}$; 3 ) the intertemporal elasticity of substitution in labor supply, governed by $\xi$; 4) the rate of depreciation of the stock of infrastructure $\left(\delta^{\mathrm{s}}\right)$ and 5) the rate of depreciation of human capital $\left(\delta^{\mathrm{h}}\right)$. Simulations are also conducted for alternative values of $\varepsilon$.

The main results of the simulation experiments for sensitivity analysis are summarized in Table 3. The top panel shows the medium-term (year 2014) and long-term (year 2049) outcomes of the economy that resorts to public investment cuts to correct its fiscal position. The bottom panel shows the corresponding behavior for the economy under the "tax-financed" alternative. Relative to the tax financing scheme, public investment cuts are systematically associated with lower tax collections (as a share of GDP) in the medium term. Across all parameter settings, tax revenues fall between $0.8 \%$ and $2 \%$ of GDP in a decade. In the longer run, those economies will require higher tax collections as well as higher tax rates to guarantee sustainability.

The conclusion that public investment compression reduces growth is robust under a wide range of parameter values, and despite the fact that fiscal consolidation is rewarded with lower interest rates. The policy lesson is that not all types of fiscal adjustment will allow for the economy to reap the benefits of fiscal consolidation. When fiscal consolidation is achieved through increasing revenues the growth toll is small (bottom panel in Table 3. Let's remember that the baseline growth rate is $3.84 \%$ ) both in the medium- and long-run. When fiscal consolidation is achieved through reducing capital spending (upper panel), the growth rate cost is positive and in some cases very sizable. The growth rate may fall by $0.2 \%$ to $0.9 \%$ in the medium run or by $0.2 \%$ to $1.8 \%$ in the long run if the reference level is the baseline rate, or may fall 0.1-0.8 percent in the medium run or $0.0 \%-1.6 \%$ in the long run if the reference point is the "tax-financed" scenario. In no scenario, capital spending cutbacks give rise to higher growth rates than under a "tax-financed" scheme. The lowest growth cost, relative to "tax-financed" scenarios, is observed when public and private infrastructure capital stocks are highly substitutable $\left(v^{\mathrm{s}}=-0.75\right)$ for each other in production, in which case there is no growth sacrifice. If the private sector is able to fully fill the gap left by the withdrawal of 
government - withdrawal from funding infrastructure investment - a fiscal consolidation effort through reducing capital spending is similar, in terms of its effect on growth, to a one based on increasing taxes. It is worth mentioning in passing that Calderón, Easterly and Servén (2003) estimate a strong positive statistical association between public and private infrastructure in Latin America, suggesting that the two are complements rather than highly substitutes.

Finally, alternative values for the semi-elasticity of the credit spread induce a time-series behavior similar to that observed under the benchmark parameterization.

\section{EXPANDING SPACE FOR PUBLIC INFRASTRUCTURE INVESTMENT}

Based on the current EU debate on fiscal rules, some alternatives have been proposed to ameliorate the growth consequences of fiscal austerity. In this subsection some of these alternatives are briefly reviewed from the perspective of economies with sustainability problems, an important consideration in planning to adopt this sort of fiscal rules. The adoption of such fiscal rules is impractical in countries like Colombia where in addition to concerns about the sustainability of the public finances, public investment spending does not "pay for itself", a result that runs counter the conventional wisdom (see Perotti, 2004).

The Golden Rule. A proposal to increase budget flexibility is the adoption of the socalled golden rule of public sector borrowing. The golden rule recognizes the different roles of current and capital spending and recommends a dual budget to separate the two types of operations. Over the business cycle current expenditures must be equal to tax receipts and borrowing should not exceed government investment. As a result, public investment expenditures may be excluded from the computation of standard deficit measures to avoid undue pressures. Blanchard and Giavazzi (2003) propose a variant of the UK rule in which borrowing is only allowed to fund net public investment (net of depreciation).

Without entering into a discussion of issues of expenditure reclassification or of which parts of spending are classified as current and which count as investment, the main point to highlight here is that the objective of the adopted fiscal framework should not be the loosening of the fiscal policy stance. In the first place, the adopted fiscal framework must make sense in the long-run. In particular it should be consistent with government solvency. The adoption of a golden rule does not ensure the financial sustainability of the state. In the UK rule, for instance, the golden rule is accompanied by the sustainableinvestment rule: "public sector net debt as a proportion of GDP will be held over the business cycle at a stable and prudent level".

The current budgetary position of the country is not one that is appropriate for adopting a golden rule. The golden rule requires that current spending be balanced by equivalent taxation. This requirement, as seen by the forecast path of public debt, is not being satisfied. 
However, as noted by Perotti (2004), the golden rule is based - explicitly or implicitly on the notion that public investment "pays for itself" in the long run. If this were the case, investment spending does not deteriorate or even affect the long-run fiscal position and the dual budget approach is justified. Perotti (2004) tests this hypothesis within a VAR framework. A dynamic general equilibrium model, like the one developed in the preceding sections, is best suited to tackling this undertaking.

Using the steady state version of the system of equations describing the economy's equilibrium, it is possible to assess the long-run effect on macroeconomic outcomes of a permanent increase of $1 \%$ of GDP of public investment in infrastructure. Let superscript ${ }^{*}$ denote steady state allocations under the increased investment regime and denote allocations under the baseline policy stance - already computed in preceding sections (referred to as initial steady state). Public investment pays for itself if the present value of additional tax revenues plus the present value of additional public utility charges, both as a proportion of the present value of GDP under the baseline policy stance $\left(\mathrm{PV}\left(\mathrm{Y}^{\circ}\right)\right)$, is greater than 1 . Additional tax revenues are given by:

$$
\frac{\operatorname{PV}\left(\mathrm{TR}^{*}\right)-\operatorname{PV}\left(\mathrm{TR}^{\circ}\right)}{\operatorname{PV}\left(\mathrm{Y}^{\circ}\right)}=\tau^{*} \frac{\left[\frac{1+\mathrm{r}^{\bullet}+\mathrm{z}^{*}}{1+\mathrm{r}^{\bullet}+\mathrm{z}^{*}-\eta^{*}}\right]}{\left[\frac{1+\mathrm{r}^{\bullet}+\mathrm{z}^{\circ}}{1+\mathrm{r}^{\bullet}+\mathrm{z}^{\circ}-\eta^{\circ}}\right]} \hat{\mathrm{Y}}^{*} \hat{\mathrm{Y}}^{\circ}-\tau^{\circ}
$$

where TR stands for tax revenue and PV stands for present value. $\tau^{*}\left(\tau^{\circ}\right)$ corresponds to the steady state tax collection to GDP ratio under the alternative (baseline) policy regime. Additional user charges are given by the following expression

$$
\frac{\operatorname{PV}\left(\mathrm{UC}^{*}\right)-\mathrm{PV}\left(\mathrm{UC}^{\circ}\right)}{\mathrm{PV}\left(\mathrm{Y}^{\circ}\right)}=\left(\frac{\rho^{\mathrm{g}^{*}}-\delta^{\mathrm{s}}}{\eta^{*}}\right) \mathrm{S}_{\mathrm{va}}^{\mathrm{g} *} \frac{\left[\frac{1+\mathrm{r}^{\bullet}+\mathrm{z}^{*}}{1+\mathrm{r}^{\bullet}+\mathrm{z}^{*}-\eta^{*}}\right]}{\left.\frac{1+\mathrm{r}^{\bullet}+\mathrm{z}^{\circ}}{1+\mathrm{r}^{\bullet}+\mathrm{z}^{\circ}-\eta^{\circ}}\right]} \hat{\mathrm{Y}}^{*}-\left(\frac{\mathrm{\rho}^{\mathrm{g}^{\circ}}-\delta^{\mathrm{s}}}{\eta^{\circ}}\right) \mathrm{S}_{\mathrm{va}}^{\mathrm{g} \circ}
$$

where UC represents user charges received from the sale of public infrastructure services and $S_{\mathrm{va}}^{\mathrm{g}}$ is the steady state public infrastructure stock to GDP ratio.

Table 4 displays the additional tax revenues and user fees generated by a permanent increase of $1 \%$ of GDP in public investment at the central government level. The table also displays the additional revenues and user charges generated by a similar increase in current expenditures. From the point of view of tax collection, capital spending is selffinancing since the present value of tax revenues increases by more than $1 \%$ of GDP. In fact, it generates additional tax revenues for $1.44 \%$ of GDP under the baseline parameterization. However, this effect is fully offset by the fall in user charges. In the model economy, user fees correspond to the marginal cost of providing public infrastructure services and they strongly decline as the public capital stock increases 
about $15 \%$ of GDP in response to a permanent $1 \%$ of GDP increase in public investment. In building up the stock of public capital, public debt increases somewhat, pushing a subsequent increase in tax rates to ensure the sustainability of the experiment. If the automatic tax response is shut down, tax revenue increases remain high at $0.86 \%$ of GDP while the fall in user charges remains relatively unchanged.

On the other hand, an increase in current expenditures has an almost negligible effect on user charges while it raises tax revenue by $0.69 \%$ of GDP if tax rates are allowed to vary. But at unchanged tax rates no additional tax revenue is generated. The results are robust to a series of parameter sensitivity tests except when public and private capital stocks are highly substitutable $\left(v^{\mathrm{s}}=-0.75\right)$. In this case the accumulation of public capital raises both tax revenue and user charges, thus rendering capital spending self-amortizing.

The Permanent Balance Rule. The permanent balance rule (Buiter and Grafe, 2004) is based on a strong form of tax smoothing. It says that once an economy reaches its 'permanent tax rate' (the constant GDP share of taxes that ensures government solvency), that is, once government solvency is guaranteed, temporary spending increases (not only including temporary increases in capital spending) should be financed by issuing debt.

The rule increases budget flexibility by allowing for borrowing to fund temporary increases in expenditures with the proviso that default is ruled out. Otherwise, the rule does not make sense in the long run. Again, the adoption of a permanent balance rule is not relevant at this juncture. The tax rate in the Colombian economy is not ensuring public sector solvency either now or in the future. As shown by the simulation results, substantial tax increases are required in the future to ensure sustainability.

However, aside from the countercyclical management of public spending where no deterioration of the government's finances is expected if spending is allowed to increase in contractionary phases of the business cycle and then reduced sufficiently during the next upswing, there is still an open question: the long-run budgetary consequences of a temporary increase in capital expenditures to assess whether a temporary increase pays for itself in the long run or if it ends up deteriorating the fiscal position and eventually violating the government's transversality condition.

The dynamic behavior of the economy is studied using impulse response analysis. Impulse response functions generated by the model trace the response of the economy over time to a $1 \%$ of GDP innovation in capital spending carried out by the central government. The experiment assumes that the economy starts from the initial steady state $^{15}$. Once the economy's transition path has been computed it is possible to estimate additional user charges and tax collections. Their present value figures are computed over a truncated horizon of 1200 periods. Given the nature of the experiment - i.e., a temporary capital outlay leading to a temporary increase in the public capital stock additional depreciation charges may be used to pay for investment spending in absence of a maintenance obligation.

${ }^{15}$ A description of the methodology can be found in King, Plosser and Rebelo (2002). 
Table 5 displays the present value of the additional tax revenues, additional user charges and additional depreciation charges generated by transitory increases in capital and current expenditures. The results are robust. There is no evidence that government investment pays for itself. A $1 \%$ of GDP increase in capital outlays pays in the most favorable scenario (highly substitutable capital stocks) only a tenth of its cost in the long run. The long-run return of current expenditures is also very tiny. An extra peso of capital or current spending deteriorates the intertemporal fiscal position.

Commercially-Run Public Enterprises. The exclusion of commercially-run public enterprises or specific investment projects from fiscal deficit and debt targets represents an alternative way to introduce budgetary flexibility by removing constraints on investment activities carried out by these enterprises. Since this represents a simple accounting procedure it is feasible in the sense that its adoption is not logically inconsistent with the overall budget situation.

To avoid underestimating government liabilities (explicit or implicit) caused by deficient management of public enterprises where the government will have to ultimately foot the bill for any losses that these may incur, the IMF has proposed various stringent criteria for assessing whether public enterprises are commercially $\operatorname{run}^{16}$ : 1) managerial independence (pricing and employment policies); 2) relations with the government (subsidies and transfers, regulatory and tax regimes); 3) financial conditions (profitability, creditworthiness) and 4) governance structure (stock listing, outside audits and annual reports, shareholders' rights). By applying these criteria to 14 large Colombian public enterprises, the IMF has found that only one (ISA, a transmission electricity enterprise) is commercially run.

According to Fainboim and Rodríguez (2004), the bulk of public investment expenditures in Colombia (approximately 90\%) are undertaken by 20 public enterprises. The REDI report (World Bank, 2004) claims that there are a number of public enterprises which are fairly close to meeting most of the IMF criteria. If all 20 of these enterprises are excluded from fiscal targets, and they normally invest around $2.2 \%$ of $\mathrm{GDP}^{17}$, the expected behavior of the main macroeconomic aggregates will be as the one depicted in Figure 2A. The fiscal accounting (Figure 2C) changes somewhat depending on how public enterprise-government relations are regulated. Public enterprises with an important infrastructure investment activity generated an operational surplus in 2003 which was close to $1 \%$ of GDP (Table 6), where $60 \%$ of it is explained by ECOPETROL (oil enterprise). If it is assumed that surpluses are transferred to the central government, the primary balance will improve. But nothing fundamental is changing. A surplus that improves consolidated accounts will appear to improve central government accounts when public enterprises are excluded from the definition of the public sector. But the rationale for the exclusion of public enterprises is precisely the protection of their investment plans from budgetary pressures. The central government would be in a weak position to require the generation of savings and transfer of resources to finance its deficit. As a result, central government finances may deteriorate further with the

\footnotetext{
${ }^{16}$ See IMF (2004a).

${ }^{17}$ This is the average level of decentralized public sector investment during the 1994-2002 period.
} 
redefinition of the public sector. But if investment policies have been effectively constrained by budgetary policies, it is possible to have the beneficial effect of higher investment by excluded enterprises. The problem is that this approach may remove investment constraints on areas that are not the most desirable from a social point of view or where there are no infrastructure shortages.

\section{CONCLUDING REMARKS}

The standard tool for formulation and evaluation of fiscal policies in Colombia, just as in various Latin American countries, focuses primarily on fiscal deficit and gross debt targets within a static framework. The type of fiscal policy advice derived from this framework could be useful in understanding the effects of current government spending decisions but not in understanding the asset-creating nature and the intertemporal tradeoffs involved in public investment decisions. As the evidence shows, many countries in the region reduced public investment expenditures in the 1980s and 1990s in an attempt to correct fiscal imbalances. Is this type of adjustment, which is valid from a deficit accounting perspective, worthwhile in an intertemporal setting? Are the gains in terms of deficit and debt indicators worth the costs in terms of foregone growth? These are important questions for policymakers but the existing framework at their disposal does not allow them to learn what fundament fiscal reforms will do to the economy.

This paper tries to provide a better sense of those effects by developing an alternative framework for fiscal analysis and policy purposes. The case of Colombia is illustrative because the two approaches provide different perspectives on the likely transitional dynamics of the economy in the near future. The model predicts a huge solvency threat posed by the already high government debt and by expected deficits in the state pension system.

The model is then used to answer a policy question. What happens if Colombian authorities try to alleviate the pressure of unfunded pension liabilities on solvency by reducing capital spending? If the public sector as a whole shuts down its investment activity ( $2.8 \%$ of GDP), a substantial fiscal consolidation effort but still far from the required adjustment to prevent government debt (relative to GDP) from growing, the model predicts a striking outcome: public finances and therefore fiscal solvency will not improve in the medium- and long-term and the long-run rate of growth will be slashed by $1 \%$. The public policy implication of this paper is obvious: the efficacy of public investment compression to solve budgetary problems is very limited while it is important to growth. The results suggest putting little credence in the idea that public investment cuts bring the fiscal position toward solvency.

The adoption of fiscal rules such as the golden rule or the permanent balance rule to shield infrastructure investment from budgetary pressures makes little sense in the presence of sustainability concerns. To ensure sustainability these rules require a stable level of debt to GDP ratio (sustainable-investment rule) or a constant share of taxes in GDP ensuring the government's solvency now and in the future. Results also show that a 
transitory increase in public investment does not pay for itself. An extra peso of capital spending deteriorates the intertemporal fiscal position. A permanent increase largely pays for itself in terms of additional tax revenue but this effect is offset by a deterioration of infrastructure user charges, as long as public prices are determined competitively. 


\section{REFERENCES}

Ambler, S. and E. Cardia (1997) "Optimal Public Spending in a Business Cycle Model," in Hairault, J., P. Hénin and F. Portier (eds.) Business Cycle and Macroeconomic Stability. Should We Rebuild Built-in Stabilizers?, (The Netherlands: Kluwer Academic Publishers).

Arrow, K. (1962) "The Economic Implications of Learning by Doing," Review of Economic Studies, 80, p. 155-73.

Aschauer, D. (1989) "Is Public Expenditure Productive?" Journal of Monetary Economics, 23, p. 177-200.

Backus, D., P. Kehoe and F. Kydland (1994) "Dynamics of the Trade Balance and the Terms of Trade: the J-Curve?” American Economic Review, 84, p. 84-103.

Balassone, F. and D. Franco (2000) "Public Investment, the Stability Pact and the 'Golden Rule'," Fiscal Studies, 21, p. 207-29.

Banco de la República (1999) "El Informe de la Junta Directiva al Congreso," Press Release, August 2.

Available at: http://www.banrep.org/prensa/com994.htm\#agosto 2/99

Blanchard, O. and F. Giavazzi (2003) "Improving the SGP through a Proper Accounting of Public Investment," mimeo, Department of Economics, MIT.

Bohn, H. (1998) "The Behavior of U.S. Public Debt and Deficits," Quarterly Journal of Economics, 113, p. 949-63.

Bohn, H. (2004) "The Sustainability of Fiscal Policy in the United States," mimeo, Department of Economics, University of California at Santa Barbara.

Buiter, W. and C. Grafe (2004) "Patching Up the Pact. Suggestions for Enhancing Fiscal Sustainability and Macroeconomic Stability in an Enlarged European Union," Economics of Transition, 12, p. 67-102.

Calderón, C. and L. Servén (2003) "The Output Cost of Latin America's Infrastructure Gap," In W. Easterly and L. Servén (eds.) The Limits of Stabilization: Infrastructure, Public Deficits, and Growth in Latin America, (Washington: Stanford University Press and the World Bank).

Calderón, C., W. Easterly and L. Servén (2003) "Infrastructure Compression and Public Sector Solvency in Latin America," in W. Easterly, W. and L. Servén (eds.): The Limits of Stabilization. Infrastructure, Public Deficits, and Growth in Latin America, (Washington: Stanford University Press and the World Bank). 
Calderón, C. and L. Servén (2004) “The Effects of Infrastructure Development on Growth and Income Distribution," mimeo, The World Bank.

Calderón, C. and L. Servén (2005) "The Contribution of Infrastructure to Aggregate Output: An Empirical Investigation," mimeo, The World Bank.

Cantor, R. and F. Packer (1996) "Determinants and Impact of Sovereign Credit Ratings," FRBNY Economic Policy Review, October, p. 37-53.

Cárdenas, M., A. Escobar and C. Gutiérrez (1995) "La Contribución de la Infraestructura a la Actividad Económica en Colombia 1950-1994," Ensayos sobre Política Económica, 28, p. 139-87.

Collard, F. (1997) "Public Investment, Stabilization and Growth," in Hairault, J., P. Hénin and F. Portier (eds.) Business Cycle and Macroeconomic Stability. Should We Rebuild Built-in Stabilizers?, (The Netherlands: Kluwer Academic Publishers).

CONFIS (2004) Cierre Fiscal 2003, Documento Asesores 02/2004, Ministerio de Hacienda y Crédito Público, marzo 24.

Correia, I, J. Neves and S. Rebelo (1995) "Business Cycles in a Small Open Economy," European Economic Review, 39, 1089-113.

De Haan, J., J. Sturm and B. Sikken (1996) "Government Capital Formation: Explaining the Decline," Review of World Economics, 132, p. 55-74.

Devarajan, S., D. Xie and H. Zou (1998) "Should Public Capital Be Subsidized or Provided?" Journal of Monetary Economics, 41, p. 319-31.

Dolmas, J. and G. Huffman (1997) "An Exploration into the Effects of Dynamic Economic Stabilization," in Hairault, J., P. Hénin and F. Portier (eds.) Business Cycle and Macroeconomic Stability. Should We Rebuild Built-in Stabilizers?, (The Netherlands: Kluwer Academic Publishers).

Echeverry, J. L. Fergusson and P. Querubín (2004) "La Batalla Política por el Presupuesto de la Nación: Inflexibilidades o Supervivencia Fiscal," Universidad de los Andes, Documento CEDE \# 2004-01.

Available at: http://economia.uniandes.edu.co/

Eichengreen, B. and A. Mody (2000) "What Explains Changing Spreads on EmergingMarket Debt?" in S. Edwards (ed.) Capital Flows and the Emerging Economies. Theory, Evidence, and Controversies, (Chicago: University of Chicago Press and NBER).

Edwards, S. (1989) "The International Monetary Fund and the Developing Countries: A Critical Evaluation," Carnegie-Rochester Conference Series on Public Policy, 31, p. 768. 
Fainboim, I. and C. Rodríguez (2004) Inversión en Infraestructura en Colombia: Comportamiento, Evaluación, Presupuestación y Contabilización, mimeo, the World Bank.

Ferreira, P. (1998) "Public versus Private Provision of Infrastructure in a Neoclassical Growth Model,” Fundação Getulio Vargas, Ensaios Econômicos EPGE \# 339.

Glomm, G. and B. Ravikumar (1997) "Productive Government Expenditures and LongRun Growth,” Journal of Economics Dynamics and Control, 21, 183-204.

Greenwood, J., Z. Hercowitz and G. Huffman (1998) "Investment, Capacity Utilization and the Real Business Cycle," American Economic Review, 78, 402-16.

Hilscher, J. and Y. Nosbusch (2004) "Determinants of Sovereign Risk," mimeo, Harvard University.

IMF (1987) Theoretical Aspects of the Design of Fund-Supported Adjustment Programs, IMF Occasional Paper \# 55, (Washington: International Monetary Fund).

IMF (2003) Fiscal Adjustment in IMF-Supported Programs, report prepared by the Independent Evaluation Office.

IMF (2004a) Public Investment and Fiscal Policy, report prepared by the Fiscal Affairs Department and the Policy Development and Review Department.

IMF (2004b) Colombia: Third Review Under the Stand-By Arrangement and Request for Waiver of Nonobservance of Performance Criterion, report prepared by the Western Hemisphere Department, June.

Jonakin, J. and M. Stephens (1999) "The Impact of Adjustment and Stabilization Policies on Infrastructure Spending in Central America," North American Journal of Economics and Finance, 10, p. 293-308.

King, R., C. Plosser and S. Rebelo (2002) "Production, Growth and Business Cycles: Technical Appendix," Computational Economics, 20, p. 87-116.

Kose, A. (2002) "Explaining Business Cycles in Small Open Economies: 'How Much Do World Prices Matter?"” Journal of International Economics, 56, p. 299-327.

Loayza, N, P. Fajnzylber and C. Calderón (2003) "Economic Growth in Latin America and the Caribbean: Stylized Facts, Explanations and Forecasts," mimeo, the World Bank.

Lopez, H. (2004) "Macroeconomics and Inequality," mimeo, the World Bank.

Mendoza, E. (1991) "Real Business Cycles in a Small Open Economy," American Economic Review, 81, p. 797-889. 
Ministerio de Hacienda y Crédito Público (2004) El Marco Fiscal de Mediano Plazo, Junio, mimeo.

Min, H. (1998) "Determinants of Emerging Market Bond Spread: Do Economic Fundamentals Matter?" Policy Research Working Paper \# 1899, the World Bank.

Mussa, M. and M. Savastano (1999) "The IMF Approach to Economic Stabilization," IMF Working Paper WP/99/104.

Ostry, J. and C. Reinhart (1992) "Private Savings and Terms of Trade Shocks. Evidence from Developing Countries," IMF Staff Papers, 39, p. 495-517.

Perotti, R. (2004) "Public Investment: Another (Different) Look," IGIER - Università Bocconi - Working Paper.

Polack, J. (1957) "Monetary Analysis of Income Formation and Payments Problems," IMF Staff Papers, 6, p. 1-50.

Prescott, E. (1986) "Theory Ahead of Business Cycle Measurement," Federal Reserve Bank of Minneapolis Quarterly Review, 10, p. 9-22.

Romer, P. (1986) "Increasing Returns and Long-Run Growth," Journal of Political Economy, 94, p. 1002-1037.

Roubini, N. and J. Sachs (1989) "Government Spending and Budget Deficits in the Industrial Countries,” Economic Policy, 8, p. 99-132.

Sánchez, F. (1994) "El Papel del Capital Público en la Producción, Inversión y el Crecimiento Económico en Colombia," in R. Steiner (ed.) Estabilización y Crecimiento. Nuevas Lecturas de Macroeconomía Colombiana, (Bogotá: Tercer Mundo EditoresFedesarrollo).

Schmitt-Grohé, S. and M. Uribe (2003) "Closing Small Open Economy Models," Journal of International Economics, 61, p. 163-85.

Senhadji, A. (1998) "Dynamics of the Trade Balance and the Terms of Trade in LDCs: The S-Curve," Journal of International Economics, 46, p. 105-31.

Servén, L. and A. Solimano (1992) "Economic Adjustment and Investment Performance in Developing Countries: The Experience of the 1980s" in V. Corbo, S. Fisher and S. Webb (eds.): Adjustment Lending Revisited: Policies to Restore Growth, (Washington: the World Bank).

World Bank (2004) Colombia: Recent Economic Development in Infrastructure, (REDI Report) Finance and Private Sector Infrastructure Unit, Latin America and the Caribbean. 


\section{Table 1}

\section{Calibrated Parameter Values}

\begin{tabular}{clr}
\hline \hline Parameter & \multicolumn{1}{c}{ Description } & Value \\
\hline$\alpha$ & share parameter in CES consumption function & 0.8826 \\
$v$ & parameter determining elasticity of substitution between consumption goods & -0.2200 \\
$\zeta^{\mathrm{i}}$ & share parameter in CES investment function & 0.3369 \\
$v^{\mathrm{i}}$ & parameter determining elasticity of substitution between investment goods & -0.2200 \\
$\kappa$ & weighting parameter for the disutility of working time & 6.0278 \\
$\xi$ & parameter determining intertemporal elasticity of substitution in labor supply & 1.6000 \\
$\lambda^{\mathrm{i}}$ & scale parameter in CES investment function & 1.8680 \\
$\beta$ & subjective discount factor & 0.9400 \\
$\delta^{\mathrm{k}}$ & rate of depreciation of business capital stock & 0.0369 \\
$\delta^{\mathrm{s}}$ & rate of depreciation of infrastructure capital stock & 0.0400 \\
$\mathrm{r}^{*}$ & foreign borrowing rate & 0.0400 \\
$\mathrm{z}$ & borrowing spread & 0.0420 \\
$\varepsilon$ & semi-elasticity sovereign yield spread to government debt to GDP ratio & 0.3000 \\
$\omega$ & capital share parameter in the production function & 0.2394 \\
$\phi$ & infrastructure capital share in the production function & 0.1470 \\
$\zeta^{\mathrm{s}}$ & share parameter in CES infrastructure capital aggregator function & 0.4784 \\
$v^{\mathrm{s}}$ & coeff. determining elasticity of substitution between public and private infrastructure & 3.0000 \\
$\delta^{\mathrm{h}}$ & rate of depreciation of human capital stock & 0.0400 \\
$\chi$ & knowledge acquisition rate & 0.0006 \\
$\lambda^{\mathrm{s}}$ & infrastructure capital aggregator scaling parameter & 1.9995 \\
$\lambda^{\mathrm{y}}$ & production function scaling parameter & 30.1458 \\
\hline \hline & &
\end{tabular}


Table 2

Benchmark Fiscal Policy Stance (as of year-end 2003)

\begin{tabular}{lclr}
\hline \hline \multicolumn{3}{c}{ Central Government } & \\
\hline & $(\%$ of GDP) & Tax rates & $(\%)$ \\
Tax revenue & 14.1 & Consumption & 12.0 \\
Nontax revenue & 1.5 & Corporate income & 26.4 \\
Total revenue & 15.6 & Personal income & 0.9 \\
& & & \\
Current expenditure & 16.0 & & (\% of GDP) \\
Infrastructure investment & 0.6 & Debt & \\
Primary expenditures & 16.6 & Central government gross debt & 54.0 \\
Primary surplus & -1.0 & & \\
Interest payments (approx) & 4.4 & & \\
Overall budget surplus & -5.5 & &
\end{tabular}

\section{Decentralized Government}

(\% of GDP)

Return on infrastructure capital $\quad 7.1$

Other revenue (adjustment factor) $\quad 5.4$

Total revenue

12.6

Expenditures (contribution to GDP) $\quad 8.0$

Infrastructure investment $\quad 2.2$

Primary expenditures $\quad 10.2$

Primary surplus 2.4

Net Interest payments $\quad 0.0$

Debt

(\% of GDP)

Overall budget surplus

2.4

Rest of government net debt $\quad 0.0$

\section{Combined Public Sector}

(\% of GDP)

Primary surplus $\quad 1.4$

Debt

Interest payments (approx) $\quad 4.4$

Public sector net debt $\quad 54.0$

Overall budget surplus

$-3.1$ 


\section{Table 4}

\section{Is A Permanent Government Spending Increase Self-Amortizing? (\% of GDP)}

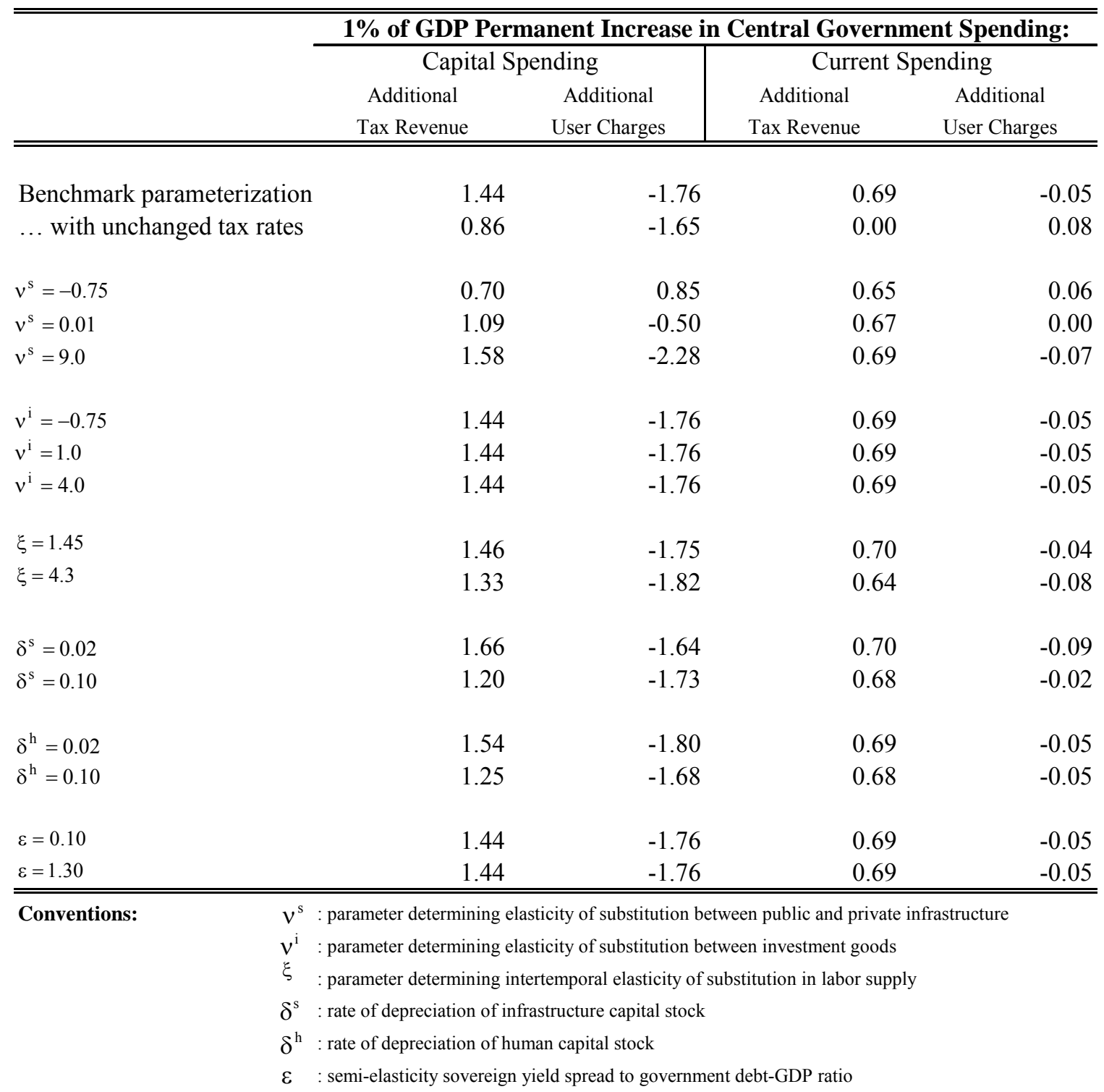


Table 5

Is A Transitory Government Spending Increase Self-Amortizing? (\% of GDP)

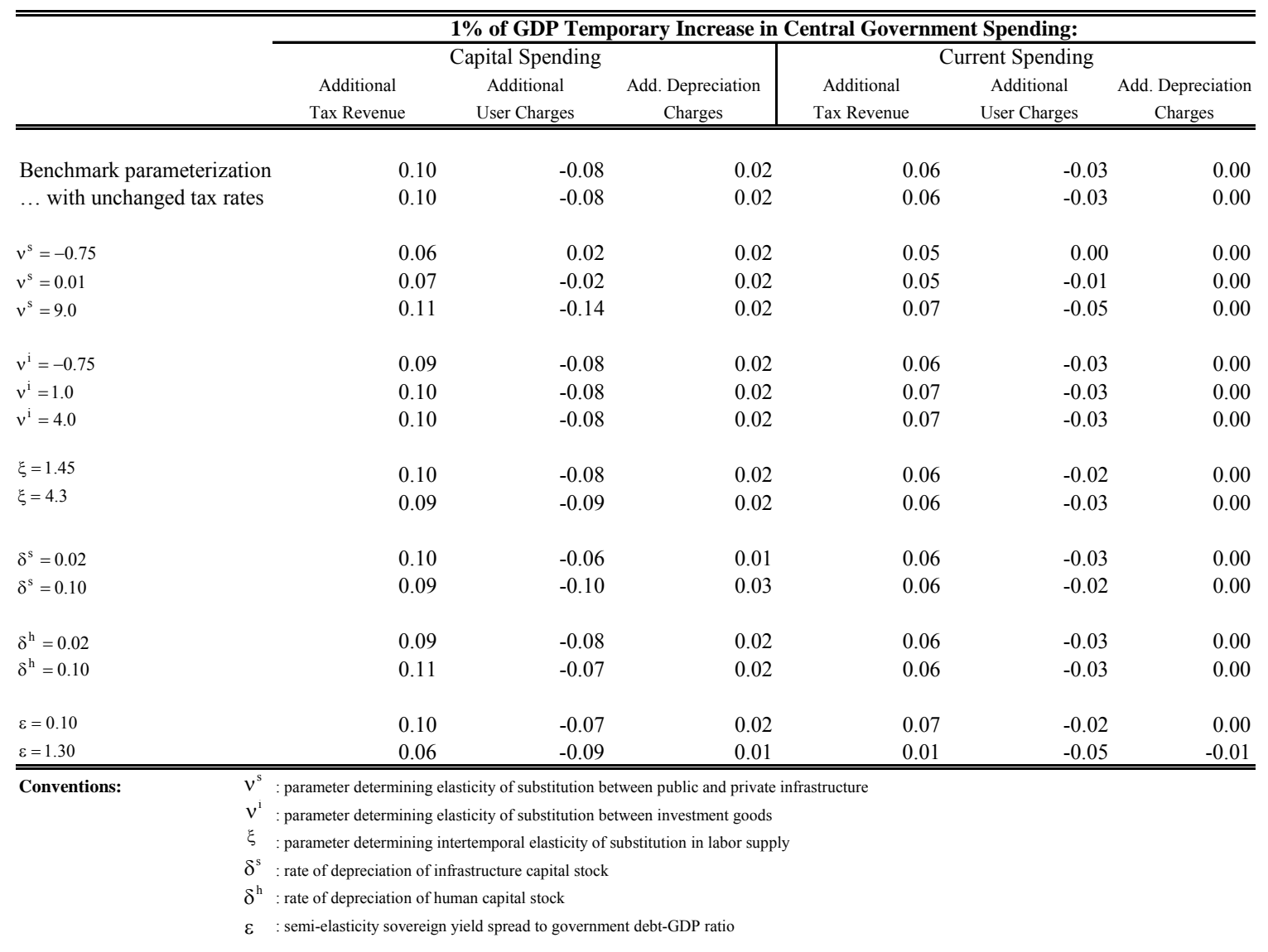


Table 6

Major Public Enterprises with Investment in Infrastructure

Debt and Overall Surplus in 2003

(\% of GDP)

\begin{tabular}{lrr}
\hline \hline Public Enterprise & Overall Surplus & Total Debt \\
\hline ISA & 0.09 & 0.61 \\
ISAGEN & 0.08 & 0.20 \\
CORELCA & 0.02 & 0.11 \\
URRA & 0.13 & 0.72 \\
CENTRALES ELECTRICAS DE NARIÑO & -0.01 & 0.00 \\
ELECTRIFICADORA DEL META & 0.00 & na \\
ELECTRIFICADORA DE SANTANDER & 0.00 & 0.01 \\
ELECTRIFICADORA DEL HUILA & 0.00 & 0.00 \\
ECOGAS & 0.06 & na \\
ECOPETROL & 0.55 & 0.16 \\
TELECOM & -0.07 & 0.10 \\
EPM & 0.00 & 0.92 \\
EMCALI & 0.17 & 0.39 \\
ETB & -0.15 & 0.09 \\
EAAB & 0.05 & 0.42 \\
ADPOSTAL & na & na \\
INDUMIL & na & na \\
SATENA & na & 0.05 \\
Total & & \\
\hline \hline SOurce: & $\mathbf{0 . 9 3}$ & $\mathbf{3 . 7 8}$ \\
\hline
\end{tabular}

Source: CONFIS

na: not available 
Figure 1

Expected Deficits of the State Social Security System (\% of GDP)

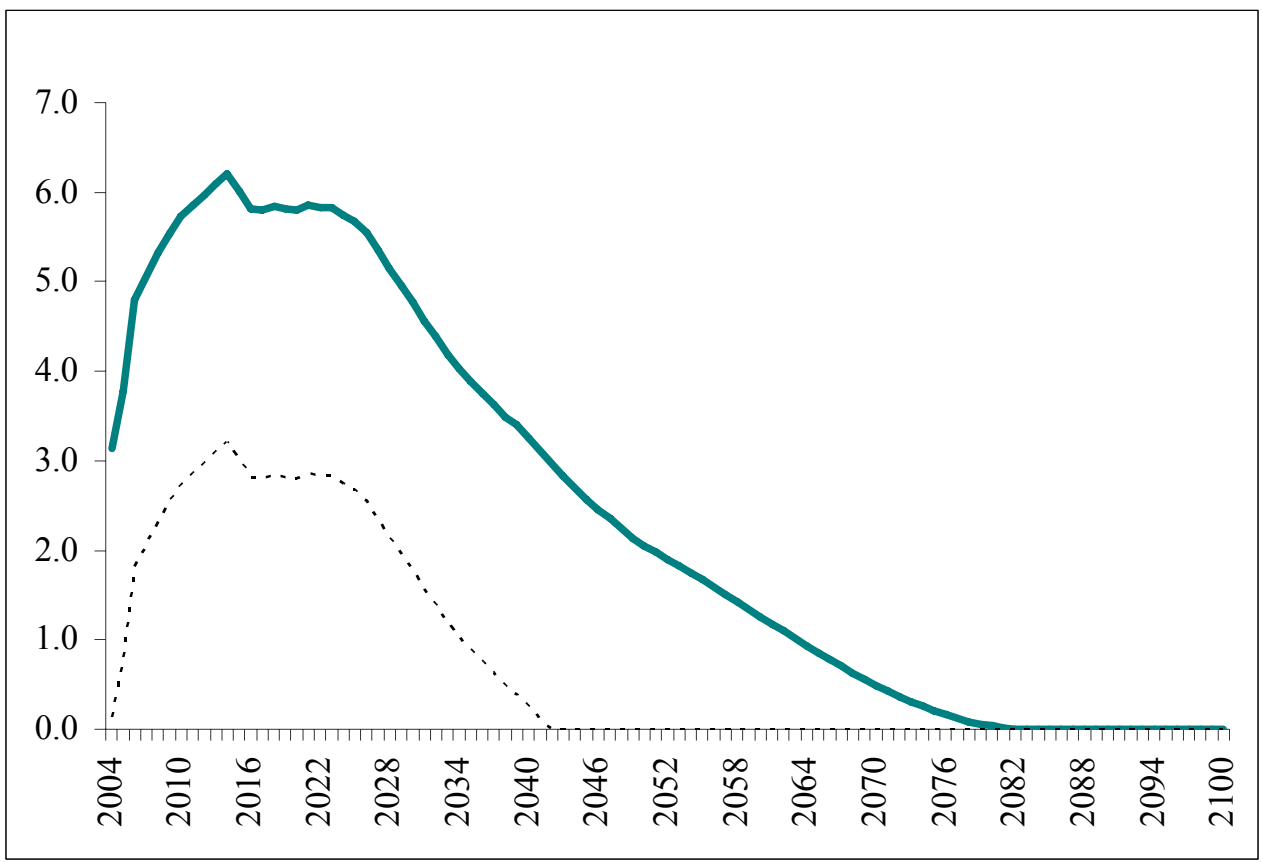

Sources: From 2004-2050: Departamento Nacional de Planeación From 2051-onward: Extrapolation 
Figure 2A

Distortionary Tax Financing:

Macroeconomic Aggregates
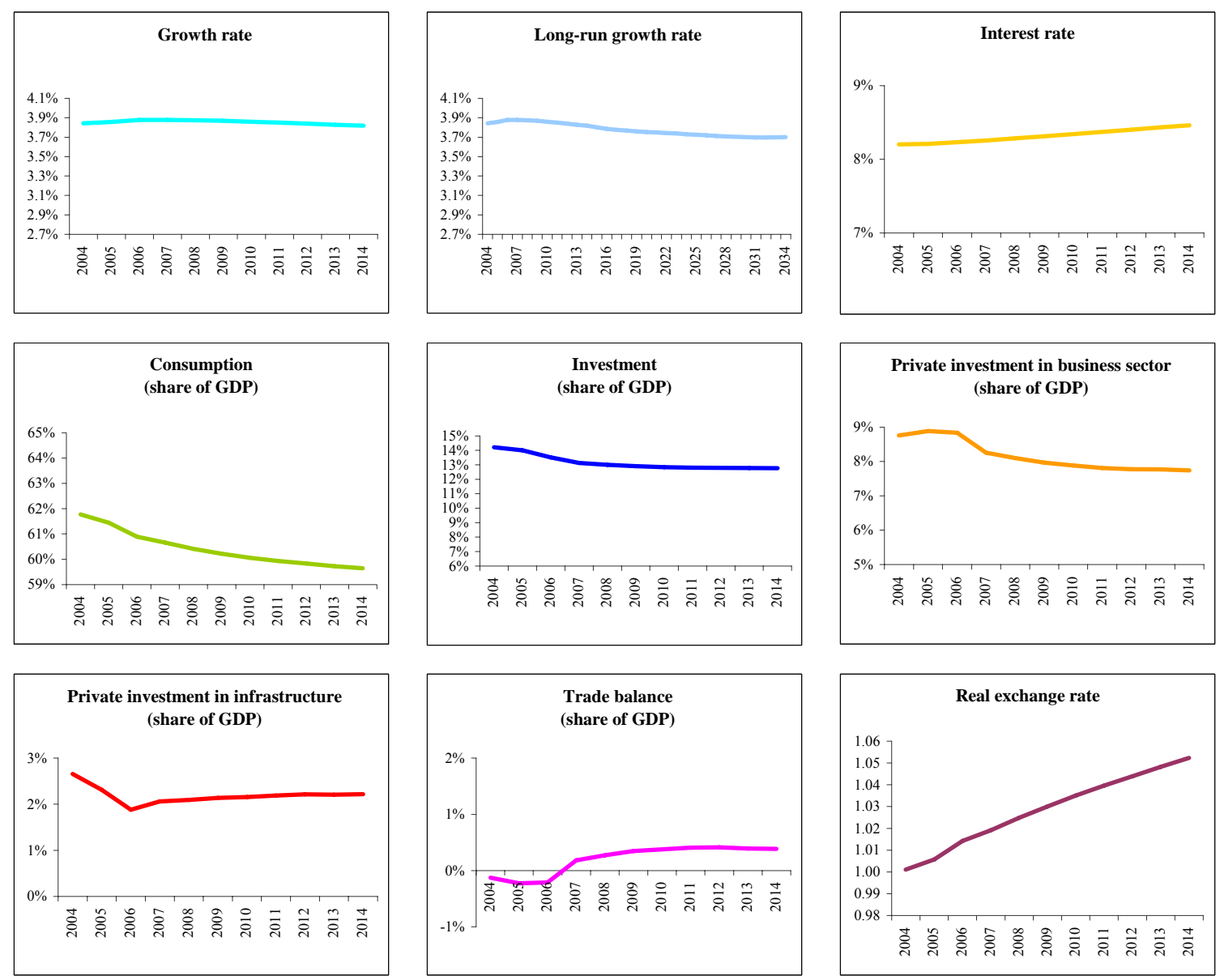
Figure 2B

Distortionary Tax Financing:

Fiscal Performance
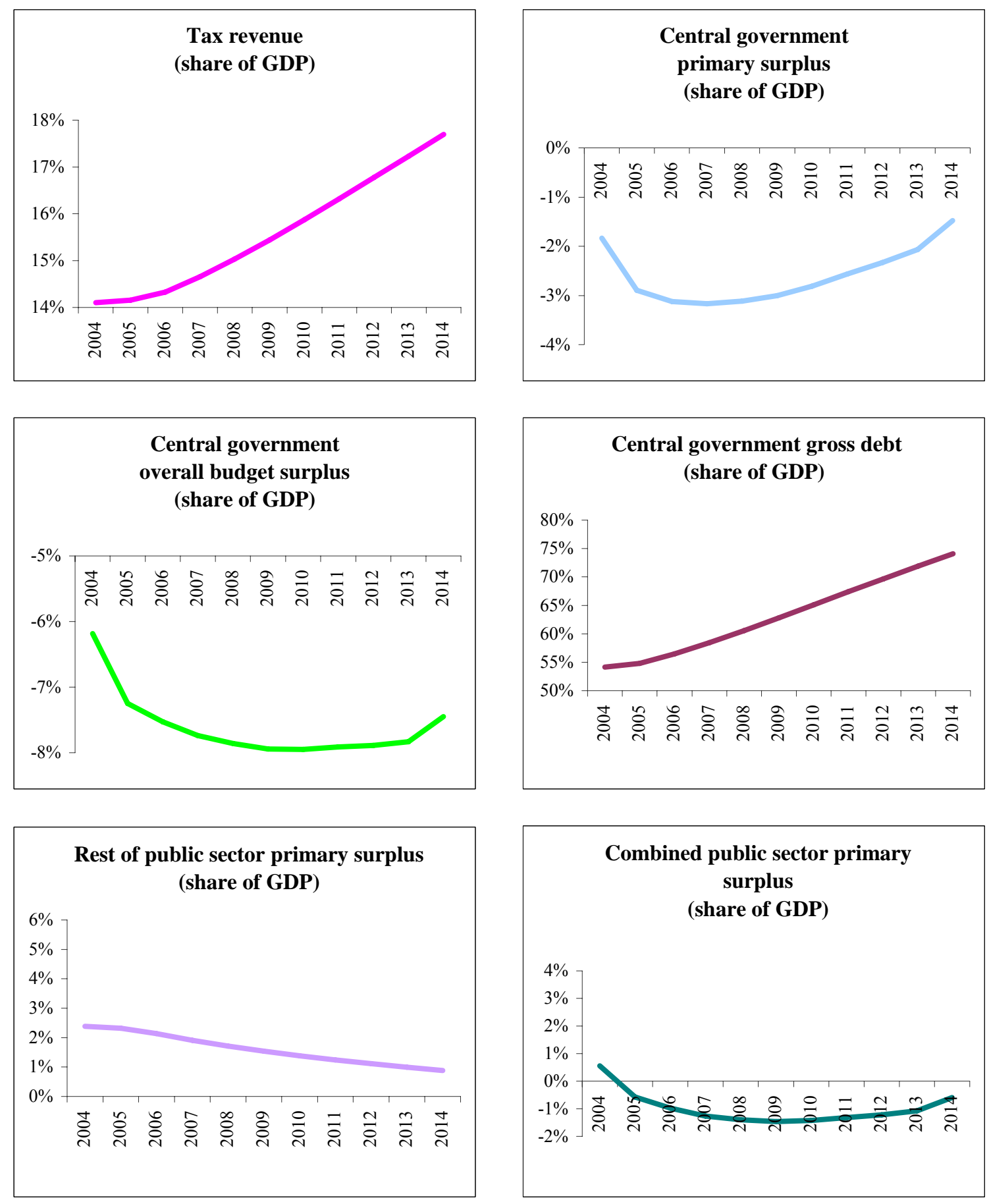
Figure 2C

Distortionary Tax Financing:

Fiscal Policy
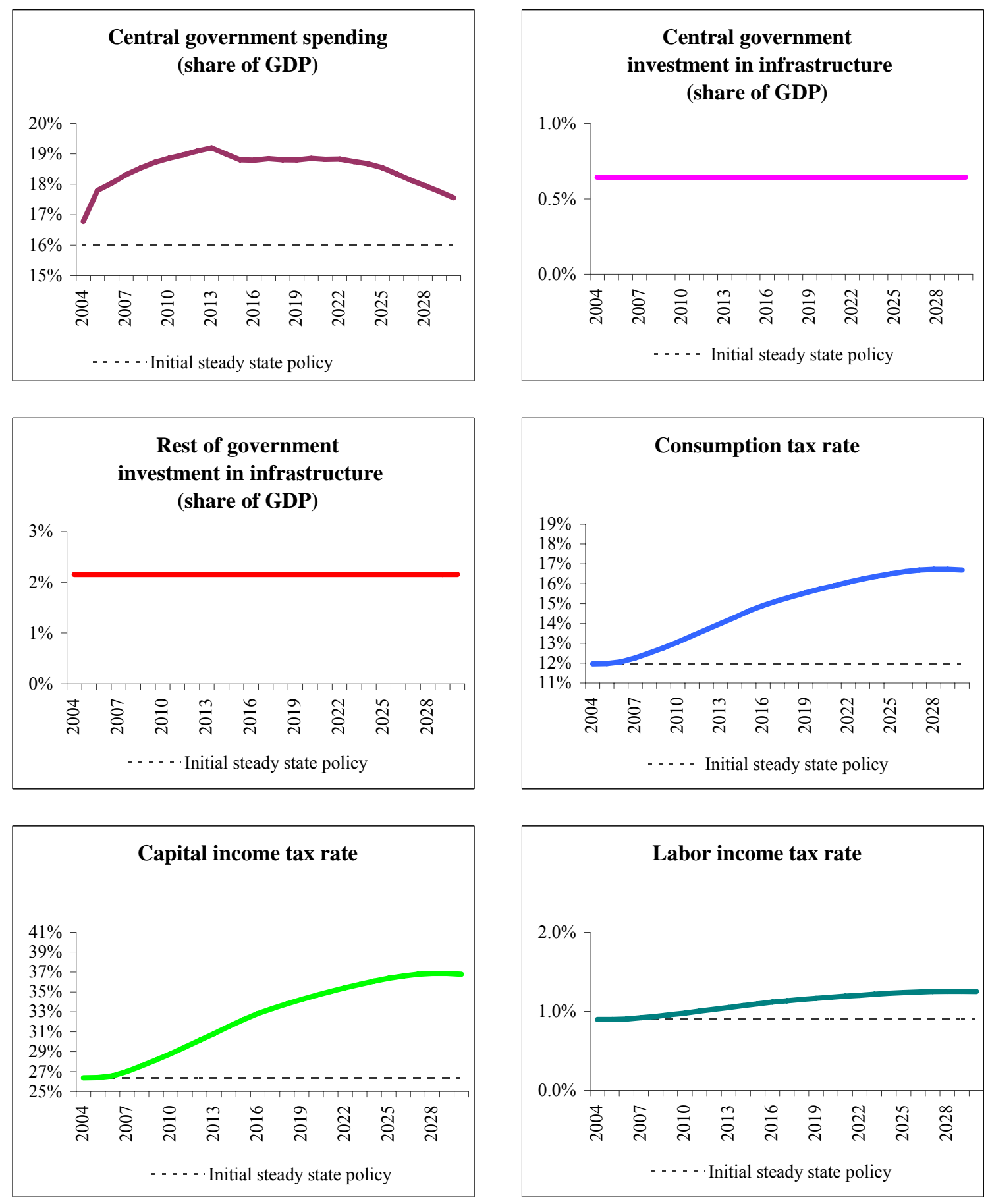
Figure 3A

Official Multiyear Economic Program: 2004-2020
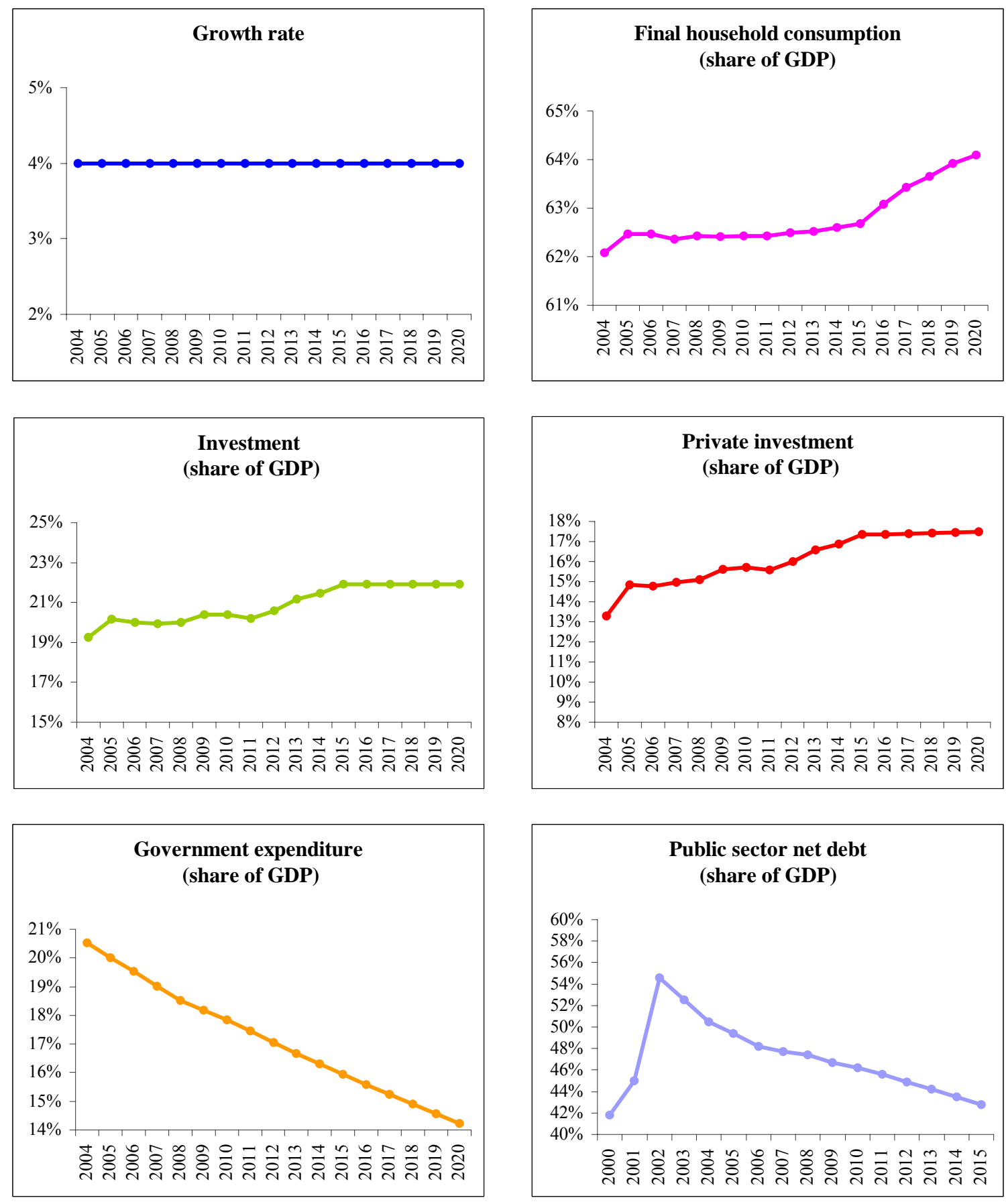
Figure 3B

IMF Baseline Projections: Colombia 2004-2010
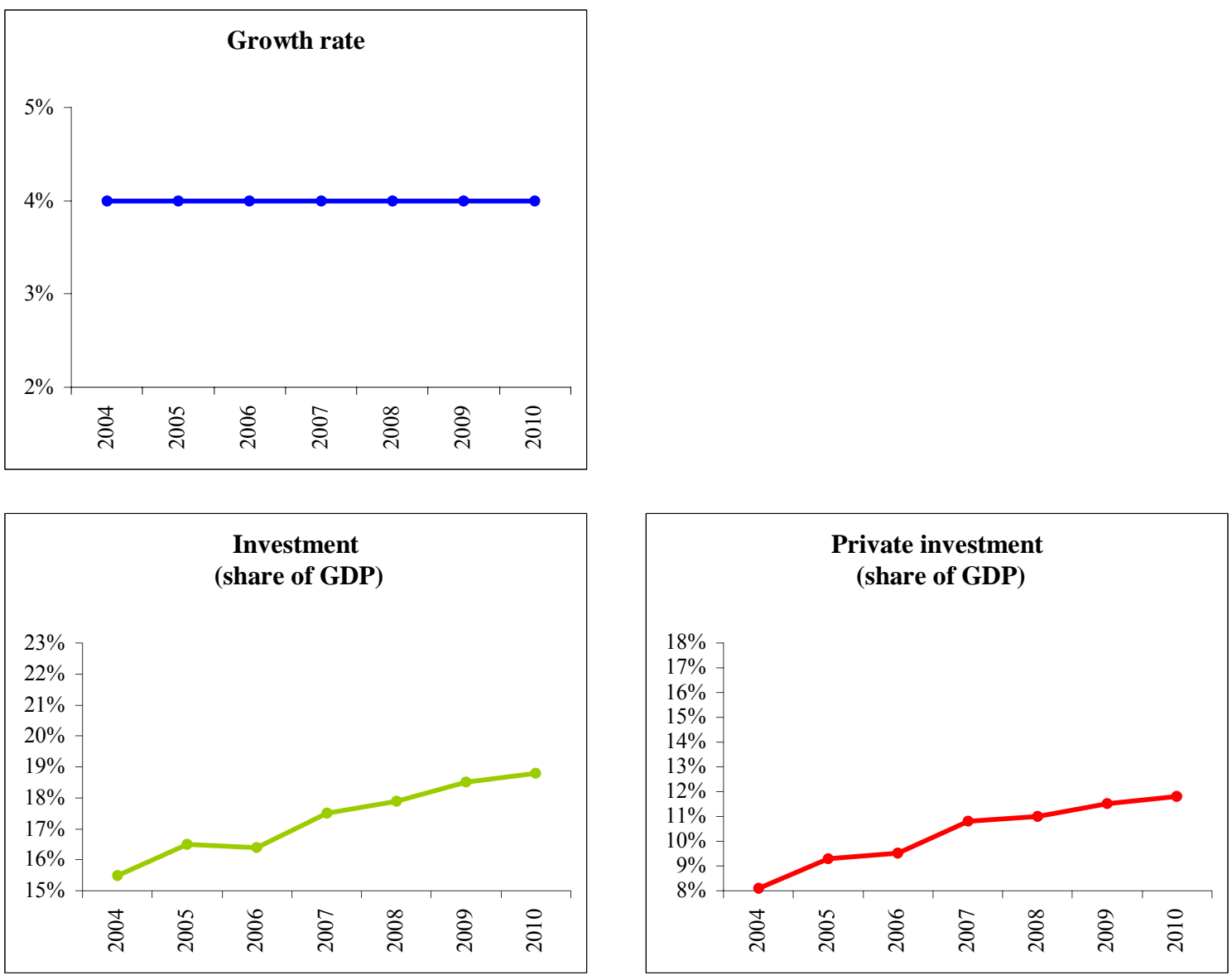

Source: IMF (2004b)

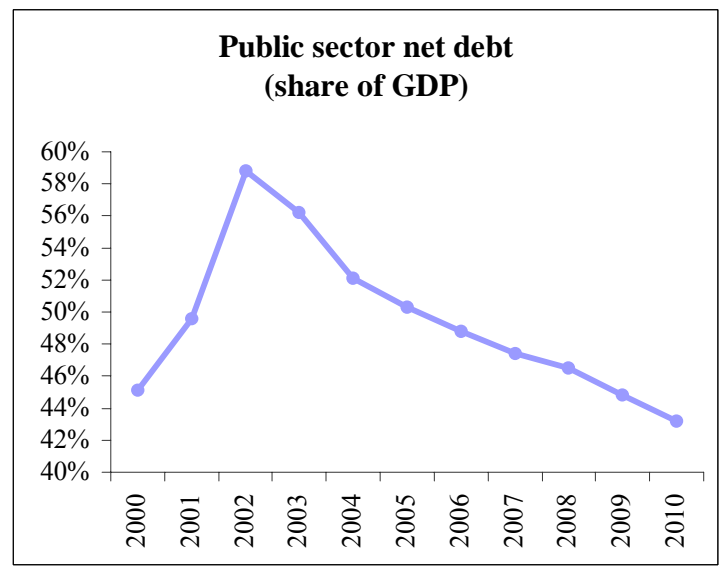


Figure 4A

Model Economy with No Central Government Investment: Macroeconomic Aggregates

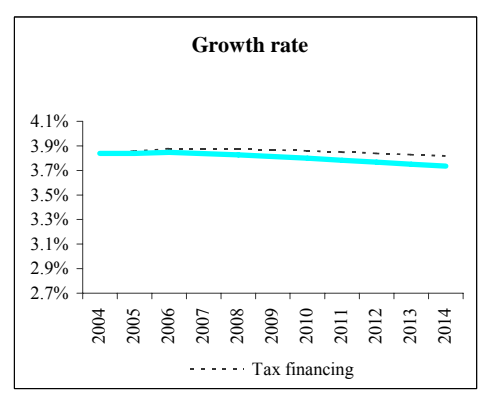

Consumption

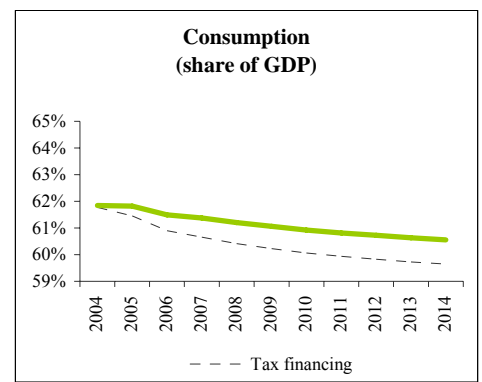

-- Tax financing

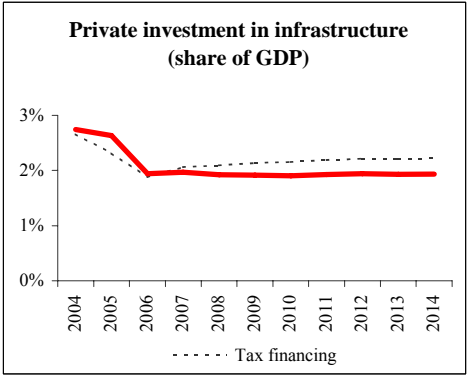

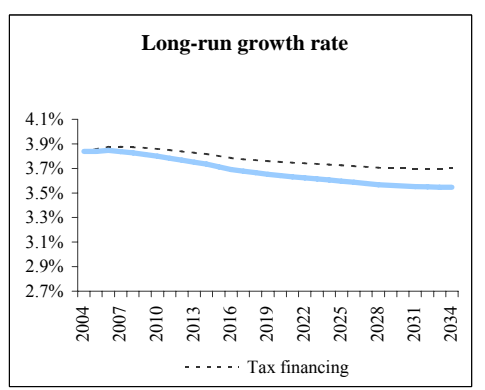
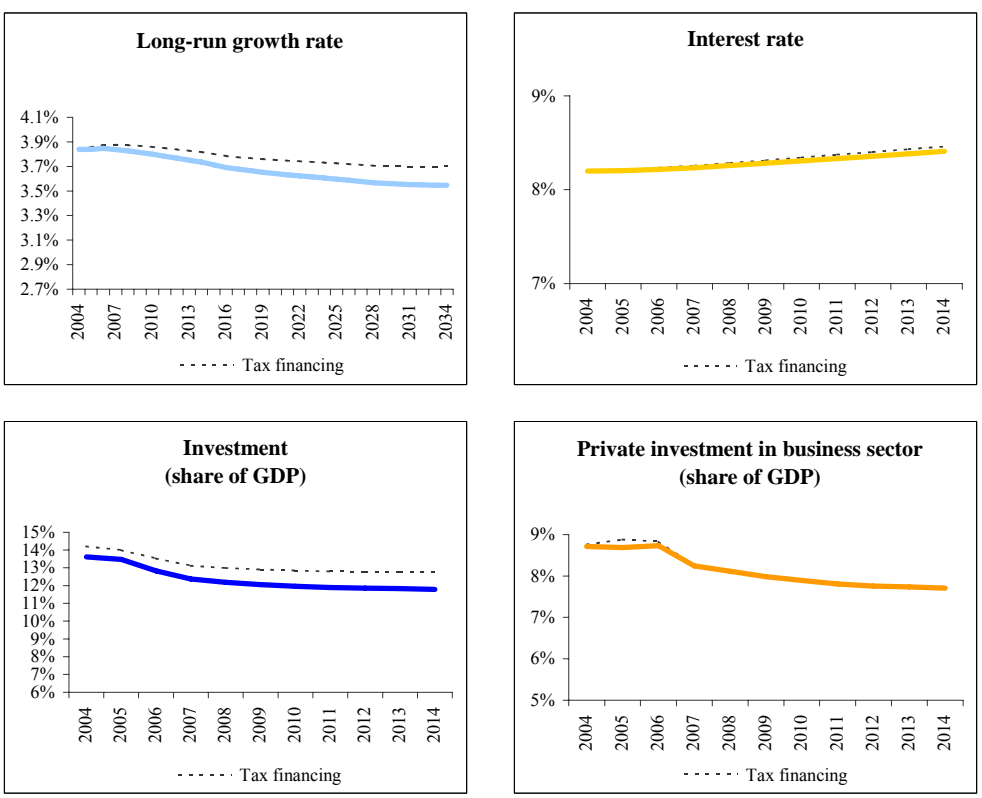

Private investment in business sector (share of GDP)
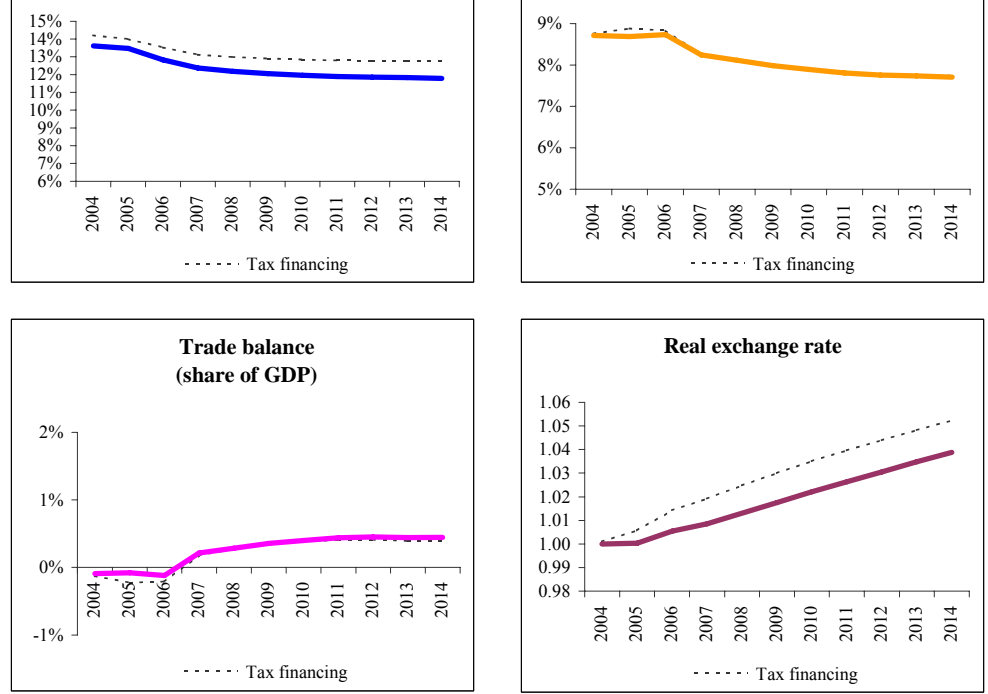
Figure 4B

Model Economy with No Central Government Investment: Fiscal Performance
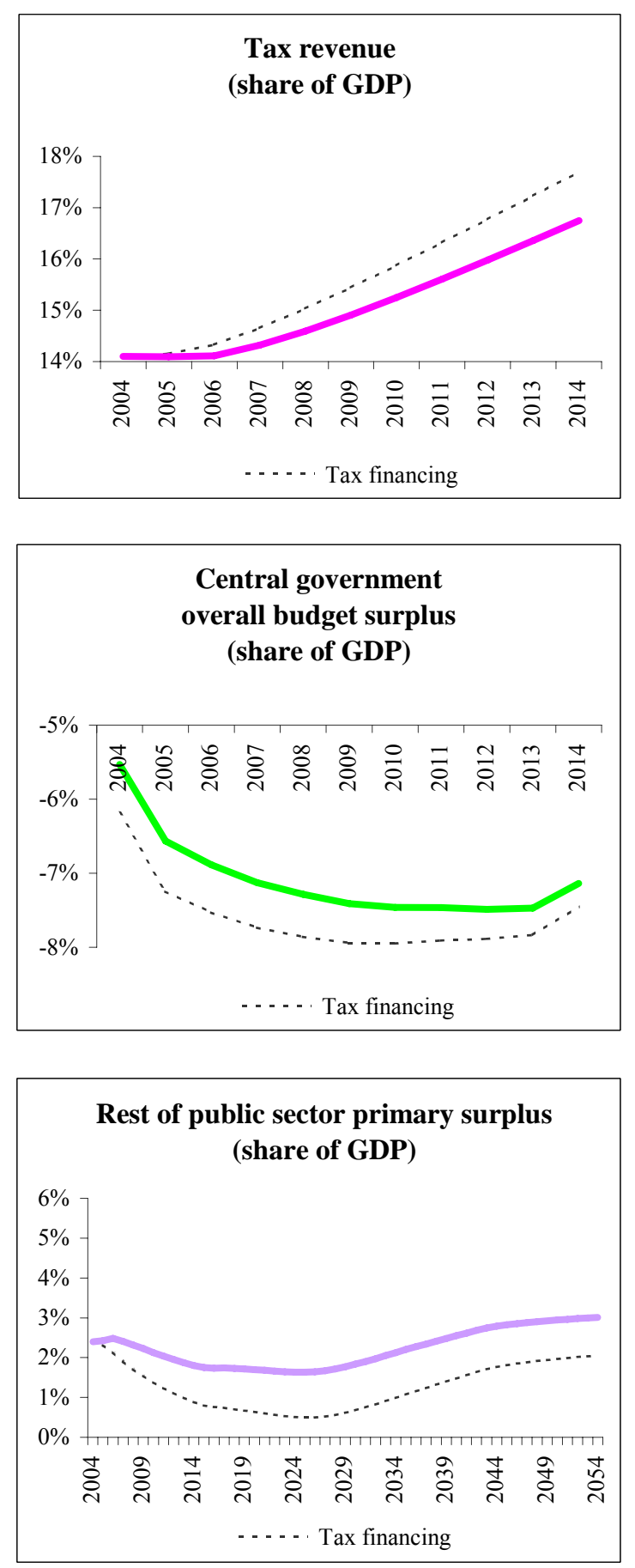
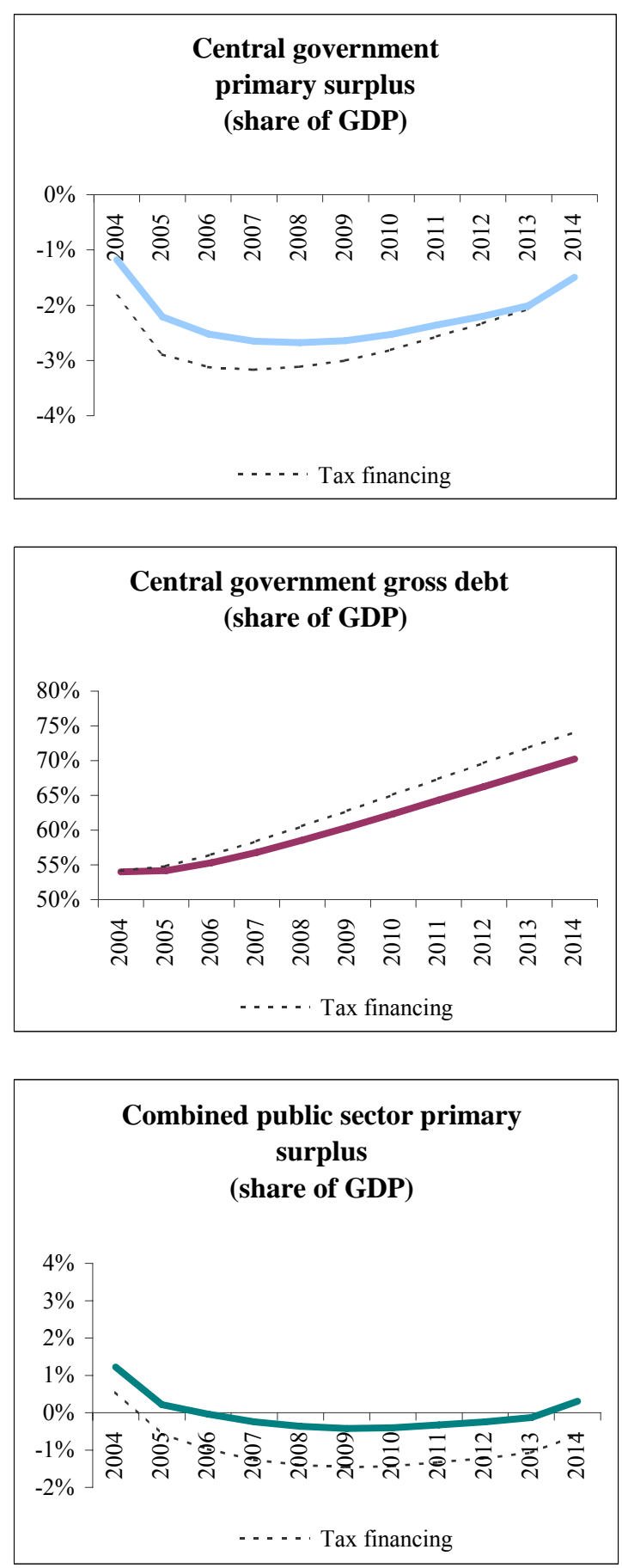
Figure 4C

Model Economy with No Central Government Investment:

Fiscal Policy
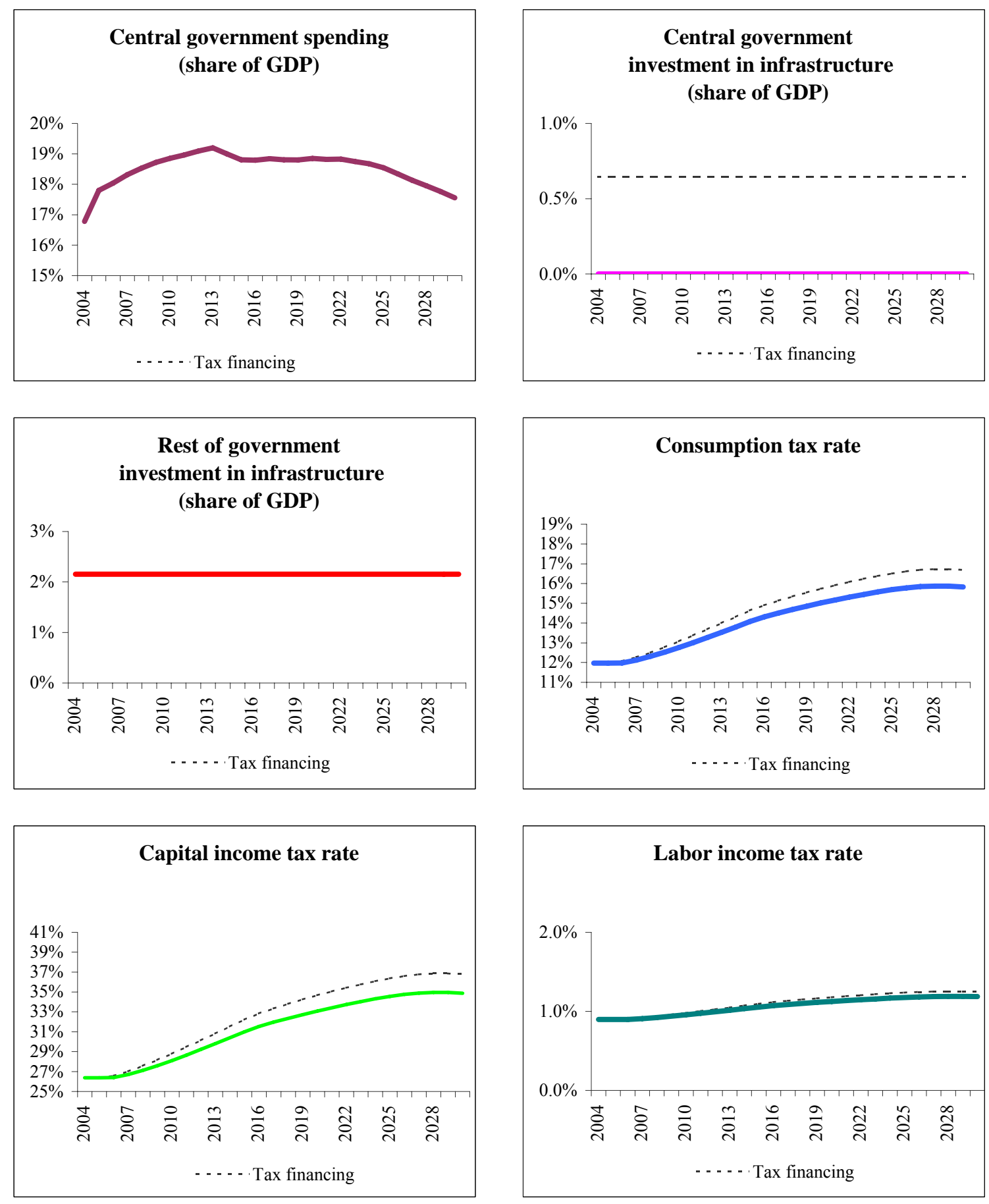
Figure 5A

Model Economy with No Public Investment:

Macroeconomic Aggregates
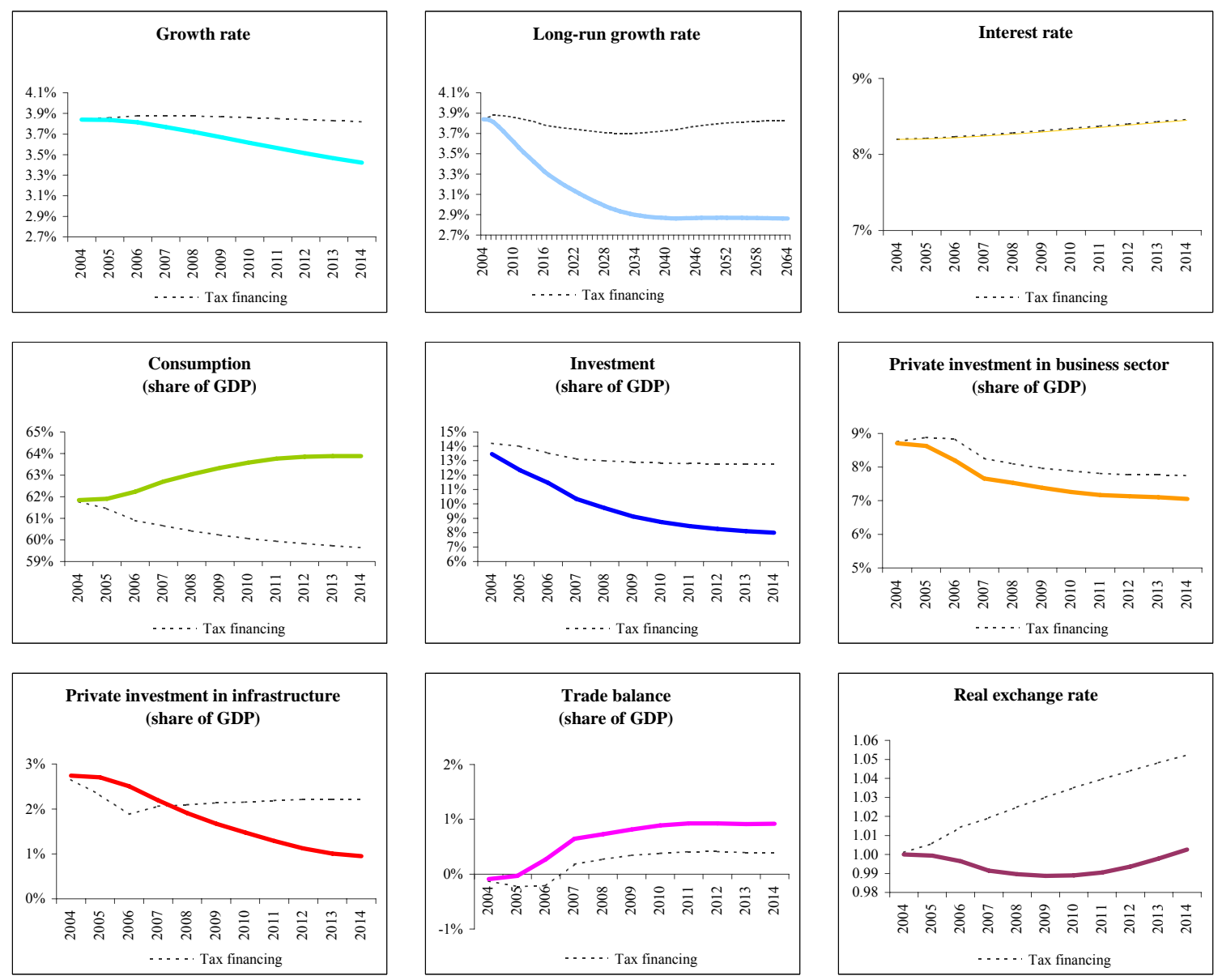


\section{Figure 5B \\ Model Economy with No Public Investment: Fiscal Performance}
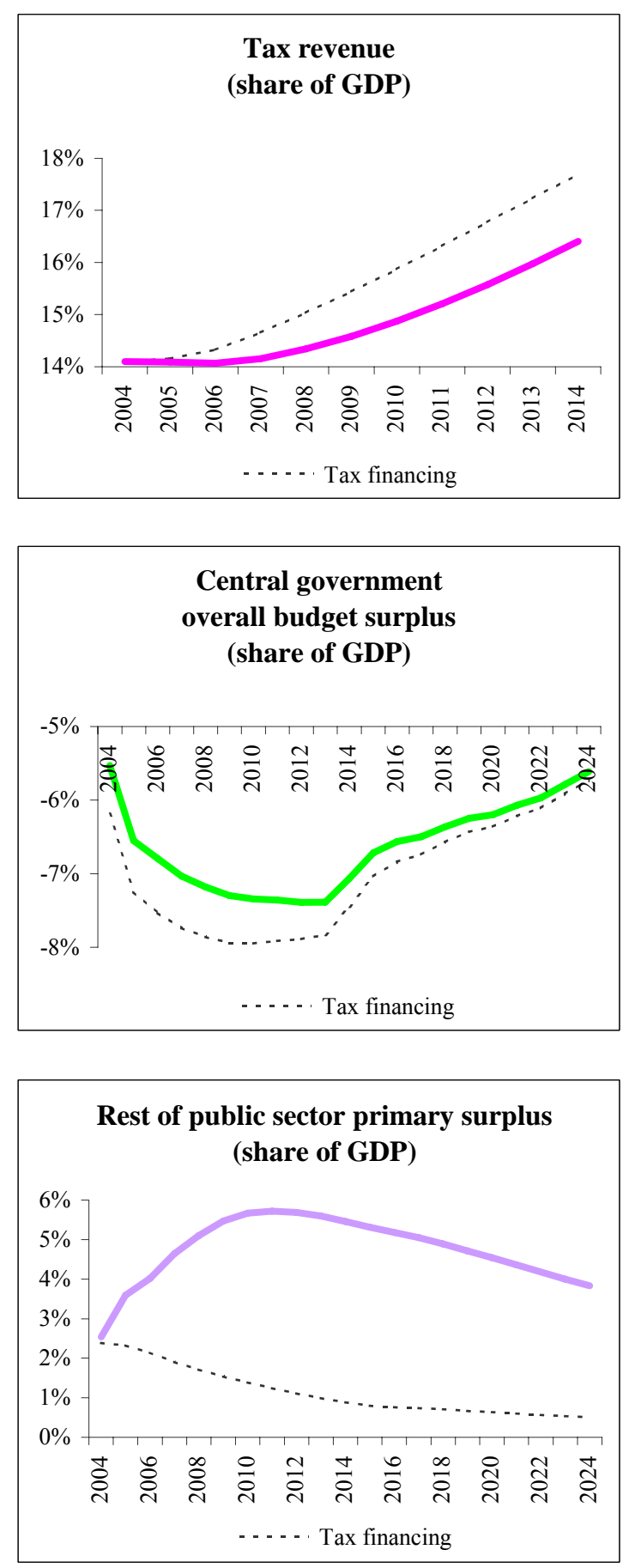
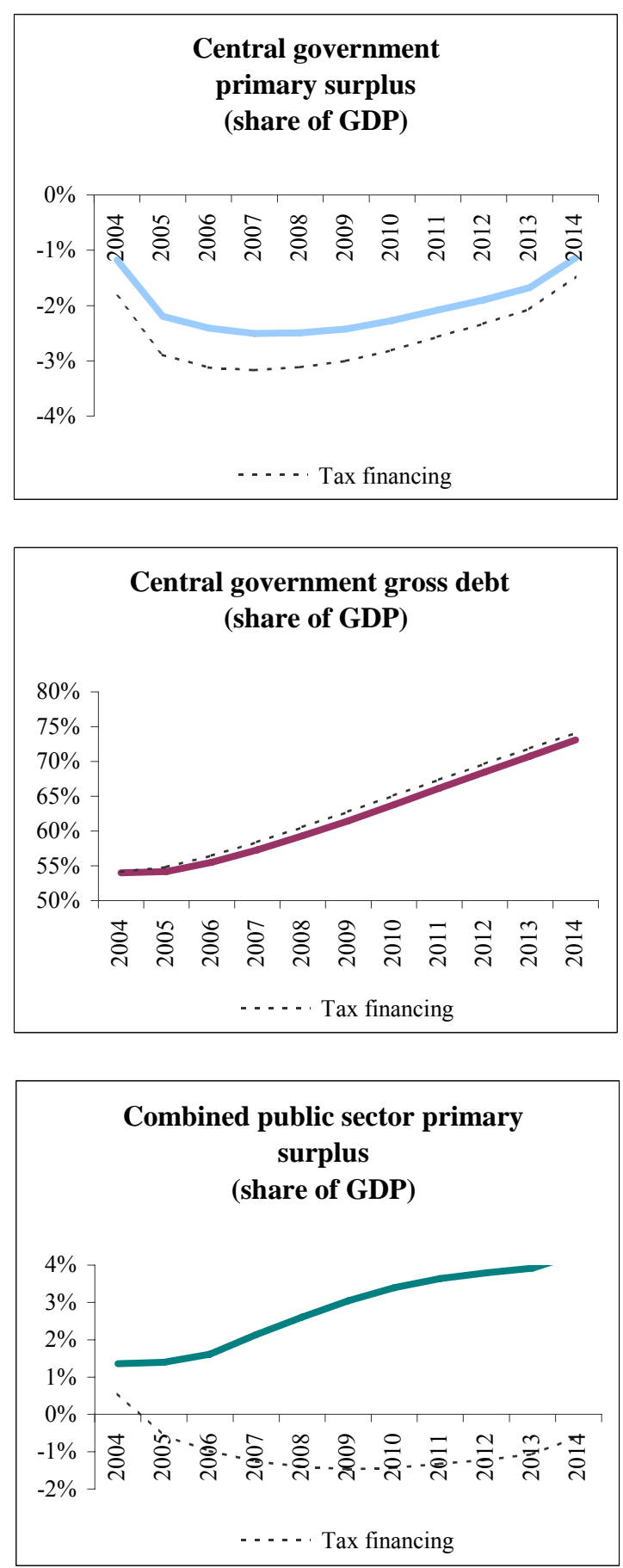
Figure 5C

Model Economy with No Public Investment:

Fiscal Policy
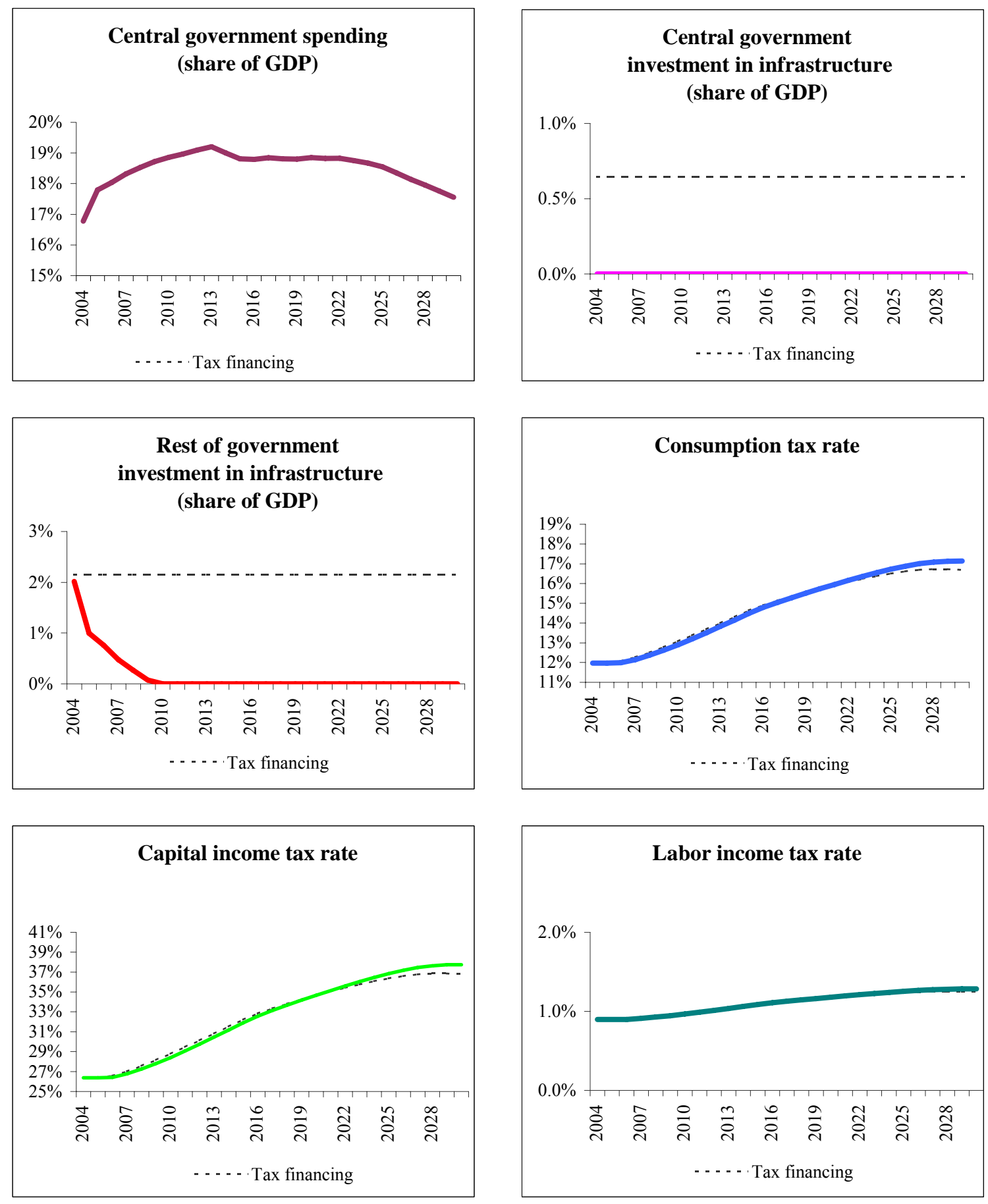
Figure 5D

Model Economy with No Public Investment: Other Features

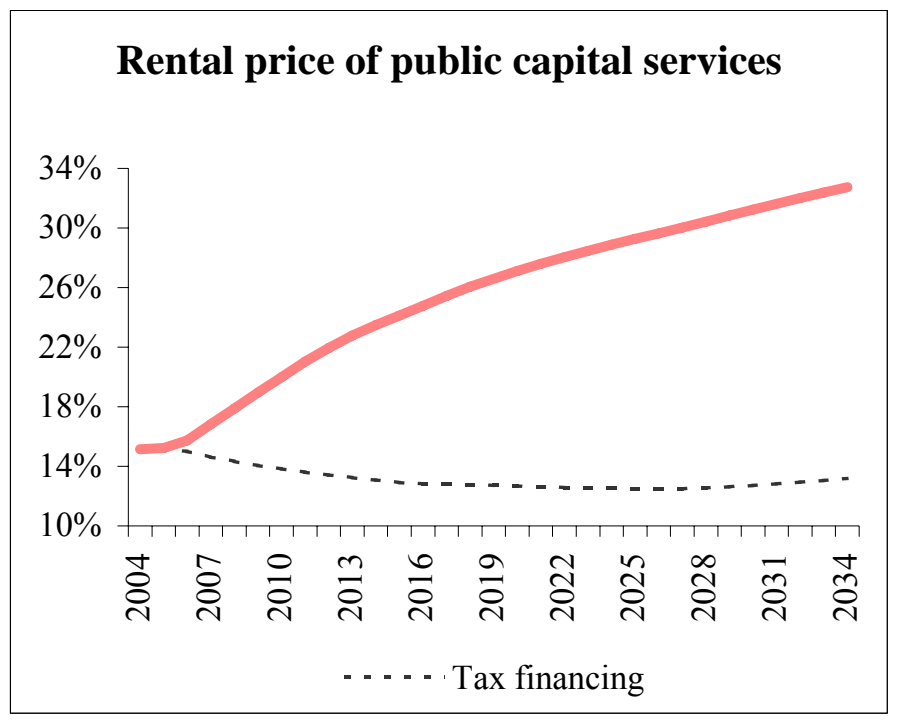

